\title{
HDL Proteome and Alzheimer's Disease: Evidence of a Link
}

\author{
Judit Marsillach ${ }^{1}\left(\mathbb{0}\right.$, Maria Pia Adorni ${ }^{2}$, Francesca Zimetti ${ }^{3, *}{ }^{\circledR}$, Bianca Papotti ${ }^{3}$, \\ Giovanni Zuliani ${ }^{4}$ and Carlo Cervellati ${ }^{4}$ (D) \\ 1 Department of Environmental \& Occupational Health Sciences, University of Washington, \\ Seattle, WA 98195, USA; jmarsi@uw.edu \\ 2 Unit of Neurosciences, Department of Medicine and Surgery, University of Parma, 43126 Parma, Italy; \\ mariapia.adorni@unipr.it \\ 3 Department of Food and Drug, University of Parma, 43124 Parma, Italy; bianca.papotti@unipr.it \\ 4 Department of Morphology, Surgery and Experimental Medicine, University of Ferrara, 44121 Ferrara, Italy; \\ giovanni.zuliani@unife.it (G.Z.); crvcrl@unife.it (C.C.) \\ * Correspondence: francesca.zimetti@unipr.it; Tel.: +39-0521-906172
}

Received: 23 October 2020; Accepted: 30 November 2020; Published: 3 December 2020

\begin{abstract}
Several lines of epidemiological evidence link increased levels of high-density lipoprotein-cholesterol (HDL-C) with lower risk of Alzheimer's disease (AD). This observed relationship might reflect the beneficial effects of HDL on the cardiovascular system, likely due to the implication of vascular dysregulation in $\mathrm{AD}$ development. The atheroprotective properties of this lipoprotein are mostly due to its proteome. In particular, apolipoprotein (Apo) A-I, E, and $\mathrm{J}$ and the antioxidant accessory protein paraoxonase 1 (PON1), are the main determinants of the biological function of HDL. Intriguingly, these HDL constituent proteins are also present in the brain, either from in situ expression, or derived from the periphery. Growing preclinical evidence suggests that these HDL proteins may prevent the aberrant changes in the brain that characterize $\mathrm{AD}$ pathogenesis. In the present review, we summarize and critically examine the current state of knowledge on the role of these atheroprotective HDL-associated proteins in AD pathogenesis and physiopathology.
\end{abstract}

Keywords: Alzheimer's disease; inflammation; vascular dementia; high-density lipoprotein; accessory proteins; apolipoprotein A-I; apolipoprotein E; apolipoprotein J; paraoxonase 1

\section{Introduction}

Dementia is a syndrome now affecting over 40 million people worldwide, and is one of the major causes of disability and death in older people [1]. In particular, Alzheimer's disease (AD) is the most frequent cause of dementia in elderly populations, with nearly $70 \%$ of patients [1].

The key pathological changes observed in AD brain tissues are the deposition of amyloid- $\beta(A \beta)$ peptides (A $\beta 1-40$ and $A \beta 1-42)$ in diffuse and neuritic plaques, and of intracellular neurofibrillary tangles (NFT), primarily consisting of abnormal and hyper-phosphorylated tau protein [2]. Additional frequent abnormalities are represented by the presence of neuroinflammation and cerebral vessel disease, with the latter affecting $60-90 \%$ of AD patients [3].

It has become increasingly clear that the role of vascular dysregulation in $\mathrm{AD}$ development is beyond that of a "static" risk factor and/or common comorbidity [4]. Indeed, ischemic and neurodegenerative pathology seem to reciprocally interact, from the earliest stage of $\mathrm{AD}$, affecting the clinical presentation and the progression of the disease [4]. As a logical consequence of this hypothesized link, every cardiometabolic risk factor can be a candidate clinical predictor of AD. High-density lipoprotein cholesterol 
(HDL-C) is an emblematic example in this regard. This inverse predictor of cardiovascular disease (CVD), which emerged from epidemiological studies, has shown a similar relationship in several prospective studies on AD, where higher levels of plasma HDL-C were associated with lower risk of developing the disease [5]. Consistently, some large cross-sectional studies have reported lower levels of HDL-C in AD patients. However, contrasting results have also been reported on this association [6,7].

In support of an association between HDL and AD, recent evidence has supported the role of HDL in preserving cognitive functions during aging. In fact, a centenarians study in Ashkenazi Jews revealed that plasma HDL-C levels are positively related with cognitive function, determined by the mini-mental state examination (MMSE), an index of cognitive performance [8]. In accordance, the Leiden 85 plus study, a population-based study in patients from The Netherlands who reached 85 years of age, indicated that median MMSE scores were significantly lower in subjects with low HDL-C, independently of CVD disease [9]. In addition, low HDL-C levels were related to a decline in memory, defined by short-term verbal memory, compared with high HDL-C levels in middle-aged adults in the Whitehall II study (London). The reported decrease in HDL-C levels was associated with memory decline independently of confounding factors, including education, employment, comorbidity, and APOE genotype, over the 5 years of follow-up [10].

A French cohort study in AD patients and control subjects evidenced lower plasmatic HDL-C levels in AD patients compared to controls [6]. Moreover, the prospective cohort, Manhattan study found that higher HDL-C levels ( $>55 \mathrm{mg} / \mathrm{dL}$ ) were associated with a decreased risk of both probable and possible AD (hazard ratio, 0.4; 95\% confidence interval, 0.2-0.9; $p=0.03$ ), also after adjustment for age, sex, education, ethnic group, and APOE4 genotype [11]. Accordingly, another study in centenarian Ashkenazi Jews (mean age of 99 years), carriers of the polymorphism $1405 \mathrm{~V}$ on the cholesteryl ester transfer protein (CETP) gene, demonstrated that low CETP levels, increased levels of HDL-C, and large HDL particles were significantly correlated with peculiar longevity, with a MMSE score in the normal range ( $>25$ points) [12].

Nevertheless, genetic polymorphisms and pharmacological strategies influencing HDL-C levels have not consistently associated with CVD risk [13-16]. Similarly, Mendelian randomization studies also suggested that HDL-C levels are not a causal risk of AD [17]. Notably, these investigations addressed only a causal relationship between disease risk and increased HDL-C levels mediated by selected genes. As elegantly highlighted by Button et al. [5], all of these studies did not examine the changes in HDL function that can occur in CVD or AD onset and progression and that can be much superior predictors of disease risk [5]. Indeed, the functional properties of HDL, and in particular the capacity of HDL to promote cholesterol efflux from macrophages, the first step of the reverse cholesterol transport, is emerging as a better predictor of CVD and in the majority of the cases independently of plasma levels of HDL-C [18,19].

HDLs are a highly heterogeneous lipoprotein family, consisting of several subclasses differing in size, shape, and lipid and protein composition $[13,20]$. The biological functions of HDLs are not limited to their role in cholesterol metabolism, but include several other vasoprotective actions, such as the enhancement of vascular function and tone, the prevention of inflammation, the counteraction of lipoperoxidation and the induction of nitric oxide secretion release and endothelial repair [20,21]. It is widely accepted that HDL function is closely related to the composition and quality of its proteome, which includes at least 204 members [22]. Apolipoprotein A-I (apoA-I) is the most abundant protein of HDLs, and its integrity is known to be pivotal for HDL global function [23]. Other important apolipoproteins are apoA-2, apoE, and apoJ, exerting various tasks in cholesterol metabolism [23].

The oxidation of apoA-I leads to a dysfunctional HDL. Martínez-López et al. [24] has recently shown that this modification is linked to impairment in cholesterol efflux and lecithin cholesterol acyltransferase (LCAT)-activating activities of the lipoprotein. There are some other components of the HDL proteome that protect apoA-I from oxidation. Among these, Paraoxonase 1 (PON1) seems to be the most effective [25]. PON1 is one of the main contributors to the atheroprotective properties of HDLs, and decrease in its activity is associated to higher risk of developing CVD, as well as other 
diseases where oxidative stress (OxS) or inflammation play a pathogenic role, including AD [26-28]. Although the crystal structure of human PON1 is not available yet, several convergent pieces of evidence have indicated that it is physically associated to apoA-I with both proteins modulating their activity reciprocally [29-31].

Some intriguing hypothesis on the role of HDL and its associated proteins in brain function and their influence on neurodegeneration, have also been formulated [5,32,33]. This influence could be indirect, due the reported beneficial effects of HDLs on the cardiovascular system, then reflected in the brain [5]. More intriguingly, the crosstalk between circulating HDL and the brain can occur via diffusion of apolipoproteins from the periphery to the central nervous system (CNS). Alternatively, the apolipoproteins may also be synthetized in situ. Indeed, apoA-I and apoE are present within the brain parenchyma, in cerebrospinal fluid (CSF) and in the cerebrovascular intima layer of the leptomeningeal artery [34]. In CSF, these two apolipoproteins are constituents of lipoproteins with a size and density similar to plasma HDL (HDL-like), which transport lipids in the brain [35]. In the present review, we summarize and critically examine the current state of knowledge on the role of selected HDL-associated proteins (Figure 1) in AD pathogenesis and physiopathology, especially focusing on under investigated aspects and suggesting potential novel mechanisms of action. A deeper knowledge on how HDL-proteins influence cerebral functions may provide promising prospective methods for the identification of novel therapeutical opportunities in neurodegenerative diseases.

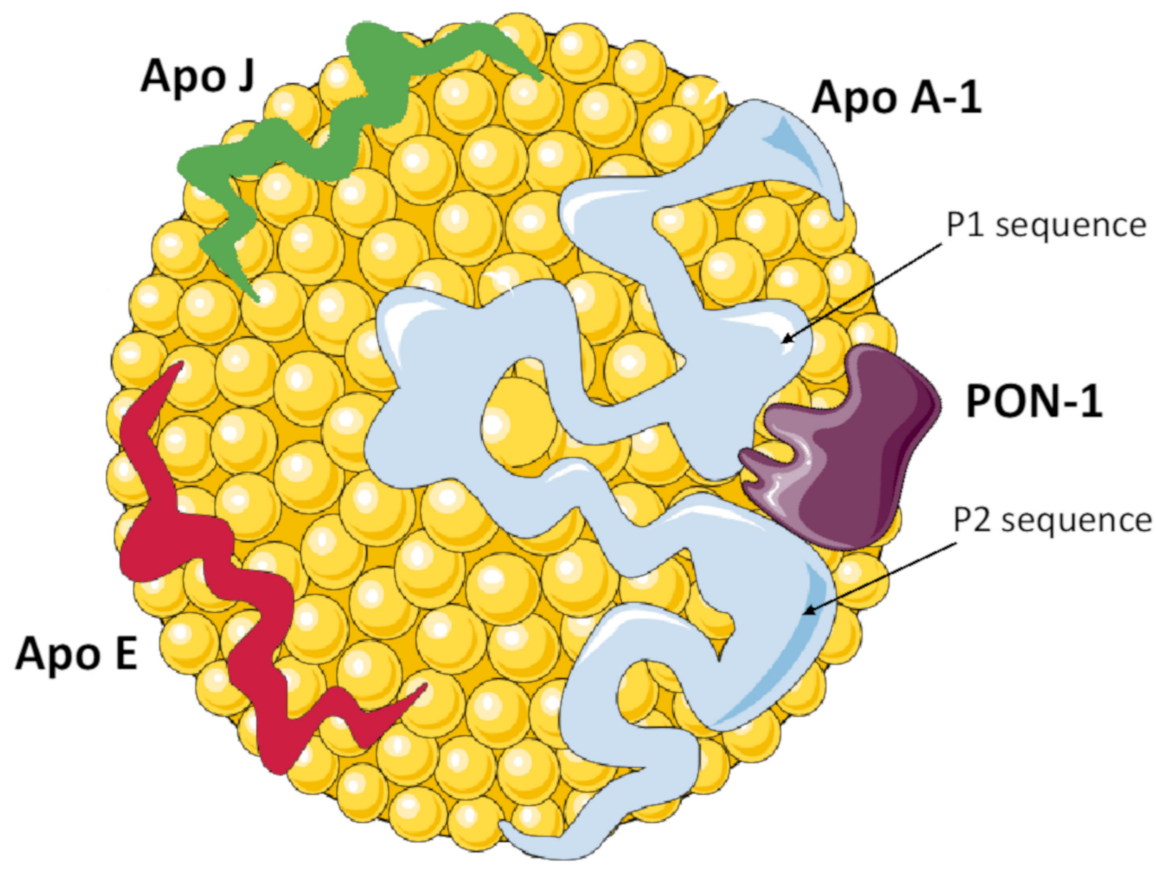

Figure 1. High-density lipoprotein (HDL) particle and its main proteome. ApoA-1 is the major protein constituent of HDL, playing a crucial structural and functional role. PON1 is present in a small fraction of HDLs, and its antioxidant activity strictly depends on its binding to apoA-1, through the interaction domains $\mathrm{P} 1$ and $\mathrm{P} 2$. Apo $\mathrm{E}$ is one of the major components of lipoprotein particles in plasma, including HDL, as well as of the HDL-like particles in the central nervous system (CNS). Apo J is expressed in different tissues and is present in biological fluids; in the CNS it is bound to HDL-like particles and seems to be involved in $\mathrm{A} \beta$ clearance.

\section{HDL Apolipoproteins}

\subsection{Apolipoprotein A-I}

ApoA-I represents the major protein constituent of HDL (70\% of HDL protein content) and it is crucial for the structural and functional integrity of the lipoprotein [36]. It is indeed largely 
responsible for mediating HDL assembly and is a determinant of HDL structure and composition. Moreover, this apolipoprotein plays a critical role in reverse cholesterol transport by enhancing the cholesterol efflux from macrophages, through an interaction with the ATP-binding cassette transporter, A1 (ABCA1). Finally, apoA-I is also a key stimulator of the enzyme LCAT, which is pivotally involved in the esterification of free cholesterol and HDL particle remodeling [37].

\subsubsection{Major Evidence Supporting a Role of Apolipoprotein A-1 in Alzheimer's Disease Pathogenesis}

The apoA-I present in the brain is thought to be primarily derived from the peripheral circulation through both the blood-cerebrospinal fluid barrier (BCSFB) and the blood-brain barrier (BBB) [34]. Several studies have suggested that apoA-I plays a critical role in preserving cerebrovascular integrity and reducing $\mathrm{AD}$ risk (Table 1).

\subsubsection{ApoA-I and $A \beta$}

Some pre-clinical studies highlighted the role of apoA-I in AD using different transgenic mouse models of AD that were used to explore the metabolism of human lipoproteins. For example, APP/PS1 transgenic mice overexpressing human apoA-I were characterized by an increase in plasma HDL-C levels, and a parallel improvement of memory deficit and attenuation of $A \beta$-associated neuroinflammation and cerebral amyloid angiopathy [32]. In accordance, Lefterov et al. [38] demonstrated that the deletion of apoA-I in the same mouse model worsened memory impairment. Moreover, in agreement with Lefterov et al., in a recent study by Button and colleagues [39], it was observed that complete loss of apoA-I increases cerebral amyloid angiopathy in APP/PS1 mice.

It has also been reported that apoA-I can affect the amyloid precursor protein (APP) processing pathway. In particular, the hypothesis is that apoA-I and HDL mediate the cholesterol efflux process, resulting in enhanced cell membrane fluidity that increases the non-amyloidogenic cleavage by $\alpha$-secretase to generate the soluble form of $A \beta$, which undergoes hepatic clearance and does not accumulate in plaques [40]. Alternatively, apoA-I could bind APP on the cell surface, avoiding the APP endocytic process, essential for $\beta$ - and $\gamma$-secretases activities and resulting in a reduced production of the neurotoxic, insoluble $A \beta$. The interaction between $A \beta$ and apoA-I with respect to $\mathrm{AD}$ pathogenesis has been recently extensively reviewed by Ciccone L. et al. [33]. A mechanism implicated in the neuroprotective effect of HDL could be the enhancement of $A \beta$ clearance. In this regard, in vitro evidence suggests that apoA-I interacts with $A \beta$ and prevents its aggregation [40]. In addition, apoA-I and HDL have a high affinity for A $\beta$ and mediate its clearance through the BBB [41]. In this respect, it has been recently reported that apoA-I lipidation state, and its conformation, could affect $A \beta$ clearance from the brain. In particular, discoidal HDL had a higher capacity to promote $A \beta$ efflux across the BBB in vitro than apoA-I in different lipidation states. In addition, discoidal HDL may disturb $A \beta$ conformation by decreasing fibril concentration and extension [42]. Recently, Contu L. et al. [43] reported that in the Tg2576 mouse model, deletion of apoA-I is associated with increased clearance of $A \beta$.

In human epidemiological studies, a French cohort study highlighted lower plasma apoA-I levels in AD patients compared with controls [6]. In the study from Slot et al. [44], higher CSF and lower plasma apoA-I levels were associated with an increased risk of clinical progression in subjects with mild cognitive impairment (MCI). In contrast, in another study [45], CSF levels of apoA-I were reduced in AD patients compared to controls. Finally, the phase II clinical trial, ASSERT (a stratified sickle event randomized trial), in which patients were treated for 12 weeks with RVX-208, a small molecule that stimulates APOA-I gene expression, showed an increase in plasma A $\beta$ levels compared to baseline. Thus, the increase in plasma apoA-I levels was associated with enhanced $A \beta$ clearance from the brain [46], with a peripheral "sink effect" that resulted in decreased A $\beta$ burden [47]. 
Table 1. Selection of preclinical and clinical evidence supporting the role of apolipoprotein A-I (apoA-I) in protecting from Alzheimer's disease (AD).

\begin{tabular}{|c|c|c|}
\hline Study & Type of Study & Main Findings \\
\hline \multicolumn{3}{|c|}{ Preclinical Studies } \\
\hline Koldamova, R.P. et al., 2001 [40] & In vitro & $\begin{array}{l}\text { ApoA-I directly interacted with amyloid precursor } \\
\text { protein and inhibited } A \beta \text { aggregation and toxicity }\end{array}$ \\
\hline Dal Magro, R. et al., 2019 [42] & In vitro & $\begin{array}{l}\text { ApoA-I mediated clearance of A } \beta \text { through } \\
\text { the blood-brain barrier }\end{array}$ \\
\hline Contu, L. et al., 2019 [43] & $\begin{array}{l}\text { In vivo } \\
\text { (animal model) }\end{array}$ & $\begin{array}{l}\text { Deletion of apoA-I was associated with increased } \\
\text { clearance of } A \beta \text { and reduced parenchymal } \\
\text { and vascular } A \beta \text { pathology }\end{array}$ \\
\hline Paternò, L. 2004 [48] & $\begin{array}{l}\text { In vivo } \\
\text { (animal model) }\end{array}$ & $\begin{array}{l}\text { Infusion of reconstituted HDL containing apoA-I } \\
\text { ameliorated the neuronal impairment through an } \\
\text { antioxidant mechanism }\end{array}$ \\
\hline Lewis, T.L. et al., 2010 [32] & $\begin{array}{l}\text { In vivo } \\
\text { (animal model) }\end{array}$ & $\begin{array}{l}\text { APP/PS1 transgenic mice overexpressing human } \\
\text { apoA-I showed an improvement of memory deficit } \\
\text { and reduction of } A \beta \text { deposition }\end{array}$ \\
\hline Lefterov, I. et al., 2010 [38] & $\begin{array}{c}\text { In vivo } \\
\text { (animal model) }\end{array}$ & $\begin{array}{l}\text { Deletion of apoA-I in APP/PS1 transgenic mice } \\
\text { worsened memory impairment }\end{array}$ \\
\hline Button, E.B. ret al., 2019 [39] & $\begin{array}{c}\text { In vivo } \\
\text { (animal model) }\end{array}$ & $\begin{array}{l}\text { Loss of apoA-I in APP/PS1 mice increased total } \\
\text { cortical A } \beta \text { deposition and astrogliosis }\end{array}$ \\
\hline \multicolumn{3}{|c|}{ Clinical/Epidemiological Studies } \\
\hline Merched, A et al., 2000 [6] & Cross-sectional & $\begin{array}{l}\text { Lower apoA-I levels in Alzheimer's disease AD } \\
\text { patients compared to controls; apoA-I levels } \\
\text { correlated with disease severity }(n=157)\end{array}$ \\
\hline Slot, R.E.R. et al., 2017 [44] & Longitudinal & $\begin{array}{l}\text { Higher cerebrospinal fluid (CSF) levels of apoA-I } \\
\text { were associated with an increased risk of clinical } \\
\text { progression in non-demented individuals }(n=429)\end{array}$ \\
\hline Johansson, P. et al., 2017 [45] & Cross-sectional & $\begin{array}{l}\text { Lower CSF levels of apoA-I in AD patients } \\
\text { compared with controls; apoA-I levels correlated } \\
\text { with the mini-mental state examination MMSE } \\
\text { score and phospho-tau (p-tau) }(n=74)\end{array}$ \\
\hline
\end{tabular}

\subsubsection{ApoA-I, Neuroinflammation, and Oxidative Stress}

Beyond the direct action on $A \beta$, further mechanisms that contribute to the protective role of HDL could be related to the antioxidant and anti-inflammatory properties of HDL. In this context, it has been observed that reconstituted HDL containing apoA-I, if administered in a rat model of stroke, ameliorated the neuronal impairment through an antioxidant mechanism by reducing reactive oxygen species (ROS) [48]. Moreover, a triple transgenic mouse model overexpressing APP and PS1 mutations together with human apoA-I (APP/PS1/AI) showed that the presence of apoA-I counteracted learning and memory impairment and reduced neuroinflammation. In particular, APP/PS1/AI mice displayed increased HDL-associated paraoxonase activity [32] and a decreased microglia-astrocyte activation compared to APP/PS1 mice. In accordance, cultured A $\beta$-induced hippocampal slides overexpressing apoA-I also showed a decreased production of the inflammatory cytokines monocyte chemoattractant protein-1 (MCP-1) and interleukin-6 (IL-6) [32]. Additionally, Button et al. [39], have recently shown that a loss of apoA-I in APP/PS1 mice increased several markers of neuroinflammation and vascular inflammation within the brain. The antioxidant activity of apoA-I could be related to the reported chaperone activity of the apoprotein, that, by complexing with $A \beta$, prevents its pro-oxidant effect [49]. In addition, apo A-I may potentiate the antioxidant activity of PON1, as discussed below. Interestingly, among the potential mechanisms explaining the anti-neuroinflammatory potential of apoA-I, there 
could be a competitive activity with the internalization of the pro-inflammatory protein serum, amyloid A (SAA), mediated by the scavenger receptor class B type I (SR-BI). In support of this hypothesis are the expression of SR-BI in human astrocytes [50] and the observation that both apoA-I and SAA are SR-BI ligands [51,52].

\subsection{Apolipoprotein E}

Apolipoprotein E (apoE) is a glycoprotein mainly synthesized by the liver, but also by several peripheral tissues, including the brain. The APOE gene displays a genetic polymorphism determined by three common alleles: APOE2, APOE3, and APOE4 [53]. The three isoforms differ only by a single amino acid substitution, leading to altered protein structure and correlated biological functions. Specifically, the APOE4 allele is widely known to be one of the strongest risk factors for developing AD [54], while APOE2 has shown neuroprotective effects [55].

ApoE is one of the major components of the HDL-like particles in the CNS, even though being present at much lower concentration compared to plasma HDL. The lipoprotein particles containing apoE are usually unable to cross the BBB, so peripheral and CNS apoE can be considered as two distinct pools [56].

\subsubsection{Major Evidence Supporting a Role of Apolipoprotein E in Alzheimer's Disease Pathogenesis}

The involvement of apoE in AD pathogenesis occurs through multiple mechanisms, including an influence on $\mathrm{A} \beta$ metabolism, but also on the tau protein and the synaptic function, as well as on neurotoxicity. In addition, apoE possesses several additional activities, including the capacity to influence brain lipid metabolism, neuroinflammation, and oxidative stress. Many of these properties, that differ among the apoE isoforms, contribute to the protective functions of the brain apoE and apoE-containing particles, with respect to neurodegenerative diseases, similarly to what occurs for plasma HDL in CVD [57]. The most important evidence linking apoE and AD is reported in Table 2.

\subsubsection{ApoE and $A \beta$}

The role of apoE in $\mathrm{A} \beta$ processing and deposition is very well known, and has been extensively reviewed elsewhere [58]. Specifically, apoE binds $A \beta$, forming complexes able to modify $A \beta$ clearance, aggregation and thus the formation of the plaques. Within this context, the isoform apoE4 showed increased $A \beta$ binding ability, and increased $A \beta$ oligomerization rate [59]. In addition, apoE4 isoform may compete with $A \beta$ for interaction with the LDL receptor-related protein 1 (LRP1), leading to reduced $\mathrm{A} \beta$ clearance and increased brain deposition [60]. This mechanism would explain the observations made in postmortem human AD brains, where the positive correlation between LRP1 and A $\beta$ levels was strengthened by the presence of the APOE4 allele [61].

\subsubsection{ApoE and Tau}

ApoE has also an influence on tau and tau-mediated neurodegeneration [58]. The isoform apoE4 worsened tau-mediated neurodegeneration in mouse models [62] and correlated with higher tau aggregates in the brain of post-mortem individuals [63]. Mechanistically, apoE4 may induce phosphorylated tau and cell injury through a heparin sulfate proteoglycan-dependent process [64].

\subsubsection{ApoE and Fragmentation}

Another important mechanism explaining the involvement of apoE in AD relates to the proteolytic cleavage that the protein undergoes in the brain, generating truncated fragments [65]. In particular, the isoform apoE4 is subjected to an enhanced proteolysis compared to apoE3, generating neurotoxic fragments [66]. In humans, apoE fragments have been detected in the AD brain at higher concentrations compared to non-AD controls, following an APOE gene-dose-dependent pattern [67]. 


\subsubsection{ApoE and Cholesterol Homeostasis}

One of the main roles of apoE in the CNS is the maintenance of cholesterol homeostasis in the brain, which occurs through the transport of newly synthetized cholesterol from astrocytes to neurons [58]. In fact, adult neurons lose endogenous synthesis capacity, and rely on cholesterol provided by other cells to ensure physiological functions [68]. Brain cholesterol transport from astrocytes to neurons occurs with astrocyte-secreted apoE that binds cholesterol and phospholipids through an interaction with the membrane transporters ABCA1, ABCG1, and remodeling enzymes [35], generating particles able to interact with the neuronal LDL receptors family, and leading to cholesterol internalization [69]. Proper apoE lipidation is thus important to preserve the brain HDL-like particle function, and the lipidation degree of these particles appears to be isoform-dependent, with apoE4 being poorly lipidated compared with apoE2 and apoE3 [70]. This results in the formation of smaller particles, as has been detected in the CSF of APOE 44 carriers when compared with APOE3 individuals [70]. Lipidation of apoE is mediated by ABCA1 activity and, in this regard, cholesterol efflux from apoE4and ABCA1-expressing astrocytes was lower compared to the efflux from apoE3-expressing cells [71]. A possible mechanistic explanation for this difference has been provided by Rawat and colleagues; they found that apoE4 displayed a reduced interaction with ABCA1 and therefore a lower lipidation degree compared with apoE3. Specifically, apoE4 induced trapping of ABCA1 intracellularly, leading to a lower ABCA1-mediated cholesterol efflux and lower A $\beta$ degradation capacity [72]. In humans, we and others $[73,74]$ have demonstrated that the CSF from mild cognitive impairment (MCI), and AD, patients showed a lower ability to induce ABCA1- and ABCG1-efflux.

As mentioned above, the HDL-like particles interact with the LDLr and other APOE-binding receptors, promoting cholesterol uptake by neurons. Alterations in the interaction between apoE and its receptors may have potential deleterious impacts on neuronal functions. For example, the proprotein convertase subtilisin/kexin type 9 (PCSK9), very well known for its regulating effect on plasma lipids [75], seems to promote the degradation of the apoE-receptors in the brain [76]. In this regard, we and others found elevated PCSK9 concentrations in the CSF of AD patients [77]. In addition, an increased PCSK9 expression in the frontal cortex from AD patients, and an association between the presence of a specific PCSK9 SNP and the risk of AD, were observed [78].

Interestingly, in individuals with a parental history of $\mathrm{AD}$, the CSF apoE levels correlate with those of PCSK9 [78], strengthening the hypothesis that PCSK9 induces the degradation of the brain apoE-receptors, leading to increased CSF apoE concentrations. In addition, a peculiar link between apoE4 and PCSK9 emerged in our study, in which CSF PCSK9 was higher in the apoE4 isoform carriers compared to non-carriers [77]. In line with this observation, individuals bearing the apoE4 isoform showed a breakdown of the BBB [79]. Based on these data we hypothesized that increased BBB permeability may facilitate the crossing of PCSK9 from the periphery, possibly helping to explain the higher concentration in the brain of apoE4 carriers. Supporting this hypothesis, the administration of a small molecule, inhibiting PCSK9, restored BBB proteins in the hippocampus, and decreased cognitive impairment in rats [80]. 
Table 2. Selection of preclinical and clinical evidence supporting the role of apolipoprotein $\mathrm{E}$ (apoE) in protecting from Alzheimer's disease (AD).

\begin{tabular}{|c|c|c|}
\hline Study & Type of Study & Main Findings \\
\hline \multicolumn{3}{|c|}{ Preclinical Studies } \\
\hline Verghese, E.P. et al., 2013 [60] & In vitro & $\begin{array}{l}\text { ApoE4 may compete with } A \beta \text { for the interaction } \\
\text { with the LDL receptor-related protein } 1 \text { (LRP1), } \\
\text { leading to reduced } A \beta \text { clearance, increasing brain } \\
A \beta \text { deposition }\end{array}$ \\
\hline Pocivasek, A. et al., 2009 [81] & In vitro & $\begin{array}{l}\text { In LPS-treated glial cells, apoE displayed } \\
\text { an anti-inflammatory action }\end{array}$ \\
\hline Wong, M.Y. 2020 [82] & In vitro & $\begin{array}{l}\text { Increased secretion of IL-1 } \beta \text { secretion in apoE4- } \\
\text { compared with apoE3-expressing microglia }\end{array}$ \\
\hline Shi, Y. et al., 2017 [62] & $\begin{array}{c}\text { In vivo } \\
\text { (animal model) }\end{array}$ & $\begin{array}{l}\text { ApoE4 worsened the tau-mediated } \\
\text { neurodegeneration }\end{array}$ \\
\hline Lynch, J.R. et al., 2003 [83] & $\begin{array}{c}\text { In vivo } \\
\text { (animal model) }\end{array}$ & $\begin{array}{l}\text { APOE4 expression associated to higher systemic } \\
\text { and brain elevations of the TNF- } \alpha \text { and IL- } 6 \text {. }\end{array}$ \\
\hline Farfel, J.M. et al., 2001 [63] & $\begin{array}{l}\text { Post-mortem } \\
\text { (humans) }\end{array}$ & $\begin{array}{l}\text { ApoE4 was associated with higher tau aggregates } \\
\text { in the brain }\end{array}$ \\
\hline Mouchard, A. et al., 2019 [67] & $\begin{array}{l}\text { Post-mortem } \\
\text { (humans) }\end{array}$ & $\begin{array}{l}\text { ApoE neurotoxic fragments were increased in } \\
\text { the brain of AD compared with controls: these } \\
\text { fragments form heteromers with } A \beta \text {, slowing } \\
\text { down its clearance }\end{array}$ \\
\hline Ramassamy, C. et al., 2000 [84] & $\begin{array}{l}\text { Post-mortem } \\
\text { (humans) }\end{array}$ & $\begin{array}{l}\text { Higher markers of oxidative stress in } \\
\text { the hippocampus of APOE4 AD patients }\end{array}$ \\
\hline \multicolumn{3}{|c|}{ Clinical/Epidemiological Studies } \\
\hline Rawat, V. et al., 2000 [72] & Cross-sectional & $\begin{array}{l}\text { APOE } 4 \text { carriers showed a reduced CSF } \\
\text { ABCA1-cholesterol efflux }(n=20)\end{array}$ \\
\hline $\begin{array}{l}\text { Marchi, C. et. al, } 2019 \text { [73] } \\
\text { Yassine H.N. et al., } 2016 \text { [74] }\end{array}$ & Cross-sectional & $\begin{array}{l}\text { CSF from mild cognitive impairment and AD } \\
\text { patients showed a lower ability to induce ABCA1- } \\
\text { and ABCG1-mediated cholesterol efflux }(n=200)\end{array}$ \\
\hline Tao, Q. et al., 2018 [85] & Longitudinal & $\begin{array}{l}\text { Only in apoE4 carriers, the presence of chronic } \\
\text { low-grade inflammation was associated with } \\
\text { increased risk of } \operatorname{AD}(n=2656)\end{array}$ \\
\hline Di Domenico, F. et al., 2016 [86] & Cross-sectional & $\begin{array}{l}\text { Presence of oxidative products in the CSF of mild } \\
\text { cognitive impairment }(\mathrm{MCI}) \text { and AD patients } \\
\text { compared to controls }(n=18)\end{array}$ \\
\hline
\end{tabular}

\subsubsection{ApoE and Neuroinflammation}

An anti-inflammatory role for apoE has been documented by several studies, and recently reviewed [59]. Among them, in lipopolysaccharide (LPS)-treated glial cells, apoE displayed an anti-inflammatory action, occurring through the c-Jun N-terminal kinase (JNK)-mediated pathway [81].

Other mechanisms, that are still to be investigated, may include a direct microglial effect on the transcription factor $\mathrm{Nf} / \mathrm{kB}$ or the inflammasome, as occurs for peripheral HDL on macrophages [87]. The anti-inflammatory effect of apoE was also highlighted in vivo, with apoE4 being associated with the highest increase of tumor necrosis factor-alpha (TNF- $\alpha$ ) and IL-6 in mouse brains [83]. In humans, the presence of chronic low-grade inflammation was associated with increased risk of $A D$, and to shorter latency of disease onset, only in APOE4 carriers [85]. 


\subsubsection{ApoE and Oxidative Stress}

ApoE may also influence oxidative stress in an isoform-dependent manner. This relationship has been demonstrated in the majority of the studies conducted in APOE knockout $(\mathrm{KO})$ mice, and reviewed by Butterfield and colleagues [88]. In the hippocampus of AD patients, markers of oxidative stress were higher in APOE4 carriers [84]. In addition, a proteomic analysis of CSF from MCI subjects revealed the presence of oxidation products before dementia was diagnosed [86].

Moreover, in human apoE4 targeted replacement mice, a reduction in the levels of the endogenous antioxidant thioredoxin-1 was observed [89], suggesting a direct effect of apoE4 on this enzyme. Other mechanisms underpinning the pro-oxidant activity of apoE4 may be related to a weaker interaction with $A \beta$, impeding the mitigation of its oxidative power, or a reduction of the activity of antioxidant enzymes. All these hypotheses need to be confirmed by future studies.

\subsection{Apolipoprotein J}

Apolipoprotein J (apoJ), also known as clusterin, is a human $80 \mathrm{kDa}$ glycoprotein first isolated in testis fluid, and identified for its aggregating or "clustering" effect on Sertoli cells [90]. In the following years, clusterin was found in different tissues under different names, according to tissue localization and function including: testosterone repressed prostate messenger-2 (TRPM-2), serum protein-40,40 (SP-40,40) [91], complement cytolysis inhibitor (CLI), sulfated glycoprotein 2 (SGP-2), and apoJ [92]. Finally, in 1992 it was concluded that all these proteins were produced from the same gene, called CLU [93]. ApoJ is expressed in different tissues, such as the pancreas, lymphoid tissue, testis, prostate, and brain [92], and is present in biological fluids; apoJ is associated with a variety of functions including complement inhibition [91], chaperon function [94], lipid transport [95], and apoptosis [96].

\subsubsection{Major Evidence Supporting a Role of Apolipoprotein J in Alzheimer's Disease Pathogenesis}

In the CNS, apoJ is mainly produced by astrocytes [97], and it seems to contribute to the clearance of $A \beta$ from the brain, due to the ability of ApoJ-containing lipoproteins to bind $A \beta$, and to be rapidly eliminated across the BBB, via low density lipoprotein-related protein 2 (LRP2) receptor [47]. The most important evidence linking apoJ and AD is reported in Table 3.

Two genomic wide association studies (GWAS) have identified the CLU gene as a novel risk factor for late-onset AD [98,99], becoming the third most common genetic risk factor after APOE and bridging integrator 1 (BIN1). Subsequently, genetic studies have discovered several single nucleotide polymorphisms (SNPs) as susceptible loci [100]. Recently, a common CLU variant (rs9331896) has been genotyped and associated with a high risk of AD and all dementia in the general population [101].

The association between apoJ concentration in brain tissue, CSF, serum, and plasma, and dementia has been extensively reviewed in a recent systematic review and meta-analysis [102]. It was shown that apoJ concentration in the plasma and brain tissues was increased in dementia compared to control, and that plasma levels of apoJ were significantly increased only in the AD group, and not in MCI or other dementias. Moreover, no association was found between serum and CSF apoJ concentration and dementia. In this meta-analysis it was thus concluded that high apoJ concentration, both in the plasma and brain, is associated with dementia. In line with this evidence, significant increases in both intracellular and secreted apoJ were found in the brain tissue of individuals with $\mathrm{AD}$, and the increase in apoJ alloforms was significantly associated with increases in both insoluble A $\beta 42$ and tau protein [103]. Furthermore, apoJ concentrations were also higher in the hippocampus and cortex of the AD brain together with A $\beta$ plaques [104], and this also occurred in the CSF [105]. Wang and colleagues [106] found that CSF apoJ levels were positively correlated with neurogranin (NG), an index of synaptic degeneration, in the control and MCI groups, but not in the AD group. However, in all subjects, apoJ levels were positively associated with NG levels, independently of age, gender, APOE4 genotype, clinical diagnosis, and CSF A $\beta 42$ levels. In addition, increased plasma apoJ 
levels have been correlated with cortex atrophy, and were also associated with a greater burden on fibrillar $\mathrm{A} \beta$ in the brain [107].

Table 3. Selection of preclinical and clinical evidence supporting the role of apolipoprotein J (apoJ) in protecting from Alzheimer's disease (AD).

\begin{tabular}{|c|c|c|}
\hline Study & Study Type & Main Findings \\
\hline \multicolumn{3}{|c|}{ Preclinical Studies } \\
\hline Yerbury, J.J. et al., 2010 [108] & In vitro & $\begin{array}{l}\text { Treatment with apoJ preserved cell viability of } \\
\text { neuroblastoma cells treated with CSF } \\
\text { supplemented with } A \beta\end{array}$ \\
\hline Nielsen, H.M. et al., 2010 [109] & In vitro & $\begin{array}{l}\text { Treatment with apoJ reduced } A \beta \text { oligomer } \\
\text { uptake in human astrocytes }\end{array}$ \\
\hline Bell, R.D. et al., 2007 [47] & $\begin{array}{c}\text { In vivo } \\
\text { (animal model) }\end{array}$ & $\begin{array}{l}\text { ApoJ contributed to the clearance of } A \beta \text { from } \\
\text { the brain }\end{array}$ \\
\hline May, P.C. et al., 1990 [104] & $\begin{array}{c}\text { In vivo } \\
\text { (animal model) }\end{array}$ & $\begin{array}{l}\text { ApoJ concentrations were increased in the } \mathrm{AD} \\
\text { brain, together with } \mathrm{A} \beta \text { plaques }\end{array}$ \\
\hline Cascella, R. et al., 2013 [110] & $\begin{array}{l}\text { In vivo } \\
\text { (animal model) }\end{array}$ & $\begin{array}{l}\text { Treatment with apoJ before the injection of } \mathrm{A} \beta \\
\text { aggregates in the brain improved learning } \\
\text { and memory performance }\end{array}$ \\
\hline DeMattos, R.B. et al., 2002 [111] & $\begin{array}{l}\text { In vivo } \\
\text { (animal model) }\end{array}$ & $\begin{array}{l}\text { Deletion of CLU gene led to reduced amyloid } \\
\text { deposition and neuritic dystrophy }\end{array}$ \\
\hline Qi, X.M. et al., 2018 [112] & $\begin{array}{l}\text { In vivo } \\
\text { (animal model) }\end{array}$ & $\begin{array}{l}\text { Administration of an apoJ mimetic peptide led } \\
\text { to an improvement of cognitive function } \\
\text { and a reduction in } A \beta \text { plaque deposition }\end{array}$ \\
\hline Shepherd, C.E et al., 2020 [103] & $\begin{array}{l}\text { Post-mortem } \\
\text { (human) }\end{array}$ & $\begin{array}{l}\text { Both intracellular and secreted apoJ were } \\
\text { increased in the AD brain; the increase in apoJ } \\
\text { alloforms was positively associated with A } \beta 42 \\
\text { and tau levels }\end{array}$ \\
\hline \multicolumn{3}{|c|}{ Clinical/Epidemiological Studies } \\
\hline Tan L. et al., 2016 [100] & Genetic & $\begin{array}{l}C L U \text { genotypes modulated the cerebral } \mathrm{A} \beta \\
\text { loads in hippocampus }(n=812)\end{array}$ \\
\hline Nordestgaard, L.T. et al., 2018 [101] & Genetic & $\begin{array}{l}C L U \text { variant was associated with a high risk of } \\
\text { AD and all dementia }(n=362,338)\end{array}$ \\
\hline Yang, C. et al., 2019 [102] & $\begin{array}{l}\text { Meta-analysis } \\
\text { (genetic studies) }\end{array}$ & $\begin{array}{l}\text { High apoJ concentration in the plasma and brain } \\
\text { was associated with dementia, especially in AD } \\
\text { patients ( } n=28 \text { studies) }\end{array}$ \\
\hline Wang, J. et al., 2020 [106] & Cross-sectional & $\begin{array}{l}\text { CSF apoJ levels were positively correlated with } \\
\text { markers of synaptic degeneration in } \\
\text { non-demented subjects and patients with MCI } \\
(n=294)\end{array}$ \\
\hline Thambisetty, M. et al., 2010 [107] & Cross-sectional & $\begin{array}{l}\text { High plasma apoJ levels were positively } \\
\text { associated with cortex atrophy }(n=844)\end{array}$ \\
\hline
\end{tabular}

\subsubsection{ApoJ and $\mathrm{A} \beta$}

With respect to the effect of apoJ on amyloid aggregation, and the consequent formation of amyloid fibrils and neuronal toxicity, a study revealed the ability of apoJ to bind different oligomers of $A \beta$, and to create long-term stable complexes, thereby influencing $A \beta$ aggregation and the formation of $A \beta$ fibrils [113]. Therefore, the ability of apoJ to sequester toxic oligomers may provide a molecular basis for the recently identified genetic association between apoJ and AD [98,99]. Indeed, conditions of reduced apoJ levels or reduced apoJ ability to form stable complexes with $\mathrm{A} \beta$ oligomers, are potentially associated to an increased susceptibility of the individual to develop AD. Consistently, the addition of 
a mix of physiological concentrations of a few chaperones, including apoJ, preserved cell viability of neuroblastoma treated with CSF supplemented with $A \beta$, and enhanced $A \beta$ uptake by macrophage-like cells [108]. In the same way, a study on rat primary hippocampal cells demonstrated that pretreatment with apoJ prevented the increase of intracellular calcium, ROS generation, and proapoptotic caspase-3 trigger, by forming complexes with $\mathrm{A} \beta$ [114]. In another study, the treatment with apoJ before the injection of $A \beta$ aggregates in the rat brain hippocampus, avoided $A \beta$-induced injury, and improving learning and memory performance, measured with the Morris maze test, and decreased inflammation and neuronal degeneration in rat brains [110].

On the other hand, with respect to the effect of apoJ on $A \beta$ clearance, numerous mechanisms have been identified; among these the promotion of $A \beta$ intracellular uptake and transport across the BBB have been reported. On the other hand, treatment with apoJ reduced A $\beta$ oligomer uptake in human astrocytes incubated with $A \beta$ in vitro [109]. Regarding the implication of apoJ in $A \beta$ transport across the $\mathrm{BBB}, \mathrm{A} \beta$ clearance was enhanced when aggregated with apoJ in vivo, through a mechanism mediated by the LRP2 receptor [47]. Recent findings obtained using an in vitro BBB model of primary cerebral endothelial cells, cultured on trans-wells to mimic the trafficking between the basolateral [115] and apical (blood) compartments, showed that the transport of labelled fluorescent $\mathrm{A} \beta$ from the basolateral to apical compartment was increased when complexes with apoJ were formed. This passage decreased when the LRP1/LRP2 pathway was blocked [116], suggesting that the relationship between apoJ and $\mathrm{A} \beta$ might be relevant for amyloid clearance in vivo.

By using animal models of amyloidosis, the correlation between apoJ and $A \beta$ in vivo has been investigated, however conflicting results have been achieved. Unexpectedly, a study by DeMattos et al. [117] showed that PDAPP mice, a transgenic mouse model of AD, which were bred to APOJ KO mice, displayed significantly reduced fibrillar amyloid deposition compared to apoJ-expressing PDAPP mice. This phenomenon was accompanied by a decreased neuritic dystrophy, which points to a pro-amyloidogenic role of apoJ. Subsequently, a second work from the same group demonstrated that the absence of both apoJ and apoE significantly increased A $\beta$ production and amyloid deposition [111].

Moreover, in another study the intracerebroventricular administration of an apoJ mimetic peptide in AD transgenic mice for 2 weeks, resulted in an improvement of cognitive function assessed by the water maze test. Immunohistochemistry analyses also revealed that amyloid plaque deposition was reduced in the apoJ-treated group, together with a reduction of brain soluble $A \beta 40$ and $A \beta 42$ levels. Finally, the treatment increased expression of LRP2, a receptor involved in A $\beta$ clearance from the brain, in the hippocampus and temporal cortex, [112]. Consistently, peripheral administration of human recombinant apoJ/clusterin in APP23 mice, induced a reduction of insoluble A $\beta$ and cerebral amyloid angiopathy in the brain [118]. In the same study an anti-neuroinflammatory effect of apoJ treatment was also observed.

In light of the above described data, apoJ certainly plays a role in AD pathogenesis via various processes, including aggregation and clearance of $\mathrm{A} \beta$, neuroinflammation and lipid metabolism modulation, and regulation of the neuronal cell cycle and apoptosis. Interestingly, apoJ levels are increased in $\mathrm{AD}$ and it decreases the aggregation of $\mathrm{A} \beta$. However, growing evidence shows that when $A \beta$ levels are much higher than those of apoJ, the amyloid generation is increased. Moreover, amyloid aggregates incorporating apoJ are more toxic compared to the A $\beta$ aggregates alone [119]. Thus, apoJ may potentially offer therapeutic opportunities to regulate $A \beta$ load in the brain, in opposition to neurodegeneration. Nevertheless, given the numerous activities carried out by this apolipoprotein, including neuroprotective and pathogenic mechanisms, it should not to be considered as a traditional therapeutic target, and further studies need to be carried out to explore novel potential apoJ-based therapeutic strategies in AD. 


\section{HDL Accessory Proteins}

\subsection{Paraoxonase 1 (PON1)}

Paraoxonase 1 (PON1) is an antioxidant, anti-inflammatory, and anti-apoptotic protein that has been studied for more than six decades, however, its physiological role is still not completely understood. This calcium-dependent enzyme is synthesized exclusively in the liver, and found in circulation mainly associated with apoA-I in HDLs. It has been shown that PON1 association with apoA-I is necessary for optimal PON1 activity/stability [31,120].The transfer of PON1 protein from HDLs to the cell membranes of certain tissues has been hypothesized, and reported by many investigators [120-125]; but the mechanism of this transfer has not been yet ascertained. PON1 was first described in 1953 for its organophosphorus hydrolyzing properties [126,127]. Almost four decades later, a new role of PON1, in preventing the oxidation of low-density lipoproteins (LDLs) [128] and HDLs [129], was reported, generating an increased interest in the study of PON1 in relation to cardiovascular disease among the scientific community. PON1 was also found to play an important role in HDL-mediated macrophage cholesterol efflux [130]. Since then, PON1 has been studied in a myriad of other oxidative stress-related diseases and in innate immunity (reviewed in $[25,131]$ ). Although the physiological substrate of PON1 remains unknown, PON1 can hydrolyze a wide range of substrates, ranging from certain organophosphate compounds [132,133], to aromatic and cyclic carbonate esters [134], lipo-lactones (lactones are believed to be the native substrate of paraoxonases) [135-137], and quorum sensing factors [138,139].

PON1 belongs to a multigene family of closely related enzymes that in mammals includes paraoxonase 2 (PON2) and paraoxonase 3 (PON3) [140]. PON2 is the only member not found in circulation. All the paraoxonases are polymorphic enzymes, with more than 200 single nucleotide polymorphisms (SNPs) described in the coding and 5' to $3^{\prime}$ untranslated regions of the PON1 gene (SeattleSNPs, https://pga.gs.washington.edu/PON1). There are two polymorphisms in the coding region, $P O N 1_{L 55 M}$ and $P O N 1_{Q 192 R}$, and one in the promoter region, $P O N 1_{T-107 C}$, which have been the focus of most studies due to their effects on PON1 concentration and/or PON1 activity [141-144]. The $P O N 1_{Q 192 R}$ polymorphism was the first one described, and the most extensively studied to date, due to its effect on PON1 catalytic efficiency towards certain substrates. The presence of polymorphisms on the PON1 gene has led, and continues to lead, to many publications studying the effects of PON1 polymorphisms on disease; almost all of them reporting conflicting results, including the few existing studies on PON1 and AD. Although some of the described polymorphisms have an effect on PON1 activity and/or concentration, there are other factors affecting PON1 levels, including age, diet, certain drugs, and lifestyle $[145,146]$. Therefore, the majority of these studies have disregarded the most important factor that determines susceptibility and risk to disease, which is PON1 levels and PON1 functionality. In epidemiological studies, since the two $P O N 1_{192}$ alloforms ( $Q$ and $R$ ) have quite different rates of hydrolysis of specific substrates, it is important to analyze the functional genotypes separately, using the assay named PON1 status [125,147,148].

\subsubsection{Major Evidence Supporting a Role of Paraoxonase 1 in Alzheimer's Disease Pathogenesis}

Oxidative stress is involved in the mechanisms of neurodegeneration, leading to AD development and progression. PON1's antioxidant activity, its presence in both plasma and CSF [28,149-151], and the documented protein localization in certain regions of the brain suggest that PON1 could play a role in the pathogenesis of $\mathrm{AD}$ and other neurodegenerative diseases [152]. As mentioned above, most of the epidemiological studies published to date regarding PON1's role in AD are contradictory, mostly due to the studies focusing on PON1 SNPs analyses rather than PON1 levels (Table 4) [149,153]. This is due to PON1 polymorphisms not being the only factor affecting PON1 activity and concentration. Studies that have focused on plasma/serum PON1 activity in relation to AD have mostly reported a consistent association between low PON1 activity in plasma or serum and AD [27,28,151,154-157]. Thus, low levels of plasma PON1 activity could be a risk factor for AD. This was not a surprising 
finding, as a decrease of PON1 activity with the progression of other oxidative stress-related diseases had already been reported [158-164]. It is likely that increased levels of oxidative stress somehow alters the structure of PON1 or the environment of PON1 in a way that decreases its enzymatic activity, resulting in a systemic decrease of antioxidant capacity and progression of disease $[165,166]$. In addition to plasma/serum, PON1 is also present in smaller amounts in CSF, as first reported by Wills and colleagues [150]. There is no known PON1 expression in the brain, however it is not known how PON1 is transferred from the liver to the CSF. One hypothesis is that it would cross the BBB bound to discoidal HDLs, which may enter the CNS via scavenger receptor class B, type I-mediated uptake or other unknown mechanisms [167,168]. Aside from the unknown mechanism of PON1 transfer to the CSF, there have been very few studies measuring PON1 activity in the CSF in relation to AD [151], as well as to other neurological diseases. In these studies, the levels of PON1 activity in CSF were significantly lower than those in plasma/serum, and therefore, it was difficult to assess if there was a significant decrease of CSF PON1 activity with the progression of disease [28,150]. Intriguingly, in our work we found that PON1-arylesterase/apoA-I ratio correlated with t-tau in the AD group [155]. More research into PON1 activity and PON1 protein in CSF is needed to determine if those measurements could be used as biomarkers of $\mathrm{AD}$, and their diagnostic value, as well as to provide more information regarding the role of PON1 in the CSF, and in AD.

Table 4. Selection of preclinical and clinical evidence supporting the role of paraoxonase 1 (PON1) in protecting from Alzheimer's disease (AD).

\begin{tabular}{|c|c|c|}
\hline Study & Type of Study & Main Findings \\
\hline \multicolumn{3}{|c|}{ Clinical/Epidemiological Studies } \\
\hline Cervellati, C. et al., 2015 [27] & Cross-sectional & $\begin{array}{l}\text { Lower serum PON1 activity in AD, vascular } \\
\text { dementia and MCI compared to controls }(n=593)\end{array}$ \\
\hline Cervellati, C. et al., 2019 [149] & $\begin{array}{l}\text { Meta-analysis } \\
\text { (genetic studies) }\end{array}$ & $\begin{array}{l}P O N 1_{S 311 C} \text { polymorphism (SS genotype) } \\
\text { and the rs705379 (but not } P O N 1_{T-107 C} \\
\text { and } P O N 1_{Q 192 R} \text { ) were associated with risk of } A D\end{array}$ \\
\hline Romani, A. et al., 2020 [151] & Cross-sectional & $\begin{array}{l}\text { PON/apoA-1 ratio was inversely related to } \\
\text { neurodegeneration (evaluated as t-tau) in AD } \\
\text { patients; no change of CSF PON1 activity } \\
\text { between AD and controls }(n=71) \text {. }\end{array}$ \\
\hline Paragh, G. et al., 2002 [154] & Cross-sectional & $\begin{array}{l}\text { Lower serum PON1 activity in AD and vascular } \\
\text { dementia compared with controls }(n=110)\end{array}$ \\
\hline Zengi, O. et al., 2011 [155] & Cross-sectional & $\begin{array}{l}\text { Lower plasma PON1 activity in AD compared to } \\
\text { controls }(n=41)\end{array}$ \\
\hline Bednarz-Misa, I. et al., 2020 [156] & Cross-sectional & $\begin{array}{l}\text { Serum PON1 activity correlated with the severity } \\
\text { of AD-related cognitive decline }(n=237)\end{array}$ \\
\hline $\begin{array}{l}\text { Bednarska-Makaruk, M.E. et al., } \\
2013 \text { [157] }\end{array}$ & Cross-sectional & $\begin{array}{l}\text { Lower serum PON1 activity in AD, vascular } \\
\text { dementia and mixed dementia compared to } \\
\text { controls }(n=433) \text {. Higher prevalence of } \\
P O N 1_{T-107 C}, \text { but not } P O N 1_{Q 192 R} \text {, in AD patients } \\
\text { than in controls }\end{array}$ \\
\hline
\end{tabular}

\subsubsection{Functional Interaction between PON1 and apoA-1: Significance in Alzheimer's Disease}

It is now well recognized that PON1 can only encounter its substrates and catalyse their transformation in vivo if the enzyme is distributed with HDL [31]. It is also becoming increasingly apparent that apoA-I and PON1 form an actual "functional couple", with one influencing the activity of the other, and vice versa [18,31]. This consideration mostly applies to PON1, which is present in a small fraction of HDLs, while apoA-I is a constant key constituent of the lipoprotein. The widely suggested physical interaction between apoA-I and PON1 within HDL structure underlies this mutual 
modulation $[29,166]$. However, it is fair to recognize that, despite great progress in this area, our knowledge of the precise interfacial activation of the two proteins still remains limited.

Combined data from functional, crystallographic, and site-specific mutagenesis studies, has concluded that PON1 activity strictly depends on its binding to HDL phospholipids and apoA-I [169]. More specifically, data reported from Huang et al. [166], suggested that two regions on apoA-I (the so-called P1 and P2 sequences) play a direct role in PON1-HDL interaction, and are fundamental for the maintenance of PON1 function. Moreover, the catalytic site of PON1 appears to be in marked proximity to the HDL-anchoring region site. This picture, although still not completely exhaustive, is consistent with previous data. Seminal studies in this field have already highlighted the close and mutual interplay between these two proteins. It was found that during isolation PON1 co-purifies with apoA-I [170]; this result was confirmed in subsequent research showing that this accessory protein is also bound to apoJ [171]. After almost a decade, Oda and coworkers [172] demonstrated, via a site specific mutagenesis approach, that apoA-I may be important in the PON1 assembly process into HDL, and functional stability.

It has been shown that apoA-I could be oxidatively modified in atherosclerotic plaques, leading to dysfunctional HDL. In particular, this modification makes the lipoprotein unable to promote cholesterol efflux and to contrast the oxidation of LDL [24]. The major culprit of this oxidative insult is myeloperoxidase (MPO) $[166,173]$. Indeed, HDLs isolated from patients affected by CVD contained high levels of 3-chlorotyrosine and 3-nitrotyrosine, products of the catalytic action of MPO $[18,166]$. At this point, $\mathrm{PON} 1$ comes on stage; apoA-I integrity seems to be preserved due to the antioxidant shield afforded by PON1 [166]. An elegant study by Huang et al. [166], suggested that MPO and PON1 may interact, within $\mathrm{HDL}$, during inflammation, with MPO promoting damaging oxidative modifications of both PON1 and apoA-I, and PON1 inhibiting MPO activity.

The aforementioned lines of evidence clearly suggest that in epidemiological/clinical studies dealing with PON1, apoA-I levels should also be assessed. In this regard, we have recently shown that PON-arylesterase/apoA-I ratio could be a useful additional parameter [13]. Consistent with this consideration, in a recent study we found that this ratio, but not PON1 activitie, is inversely associated with CSF total tau (t-tau) and p-tau, markers of NFT pathology and neurodegeneration, respectively [151]. Moreover, our preliminary (unpublished) data suggest that PON-arylesterase/apoA-I ratio might discriminate healthy controls from AD patients better than PON1-arylesterase activity. This parameter reflects the activity of PON1 per apoA1 (which is also a surrogate marker of HDL particle) and may represent a valid measure of the biological functionality of each, single HDL. An elevated PON-arylesterase/apoA1 ratio could indicate a more effective antioxidant protection towards apoA-I, and a minor extent of oxidation of this protein. Owing to this, it is tempting to speculate that this parameter could mark more properly the quality of HDL than solely PON1 activity. This could be one of the underlying reasons for some of the contrasting findings in epidemiological/clinical studies on PON1 [174-176]

\section{Conclusions}

A growing body of evidence clearly indicates an association between HDL, and its main protein components, and $\mathrm{AD}$ pathophysiology. In particular, beyond the deeply investigated role of apoE, the apolipoproteins apoA-I and apoJ may also influence the pathogenetic processes of $\mathrm{AD}$, by acting through multiple mechanisms in the CNS, including $A \beta$ processing, clearance, and transport across the BBB. In addition, the antioxidant, anti-inflammatory, and anti-apoptotic activity of PON1 has also been suggested to play a role in the pathogenesis of $\mathrm{AD}$, although data are still limited. Notably, the physical interaction between apoA-I and PON1 may explain the reciprocal influence in AD pathogenesis of these two proteins within HDL. Although wider studies will be necessary to further elucidate this aspect, the evidence collected by this review suggests both PON1 and apoA-I, and their ratio, as novel potential biomarkers useful in monitoring $\mathrm{AD}$ progression. 


\section{Future Direction and Perspectives}

Being a relatively novel topic, further efforts should be made to draw a definitive picture of the role of HDL in AD pathogenesis. Future preclinical and clinical studies should address two, still not exhaustively solved, questions: (1) the cause-effect relationship between HDL and AD, and (2) the mechanism by which HDL may protect from AD occurrence.

(1) As we have pointed out, the classic HDL hypothesis, increasing HDL cholesterol will decrease risk of CVD, has not provided the anticipated outcomes. Instead, the field is moving towards HDL functionality based on their protein cargo, with evidence already showing the importance of functional HDL in disease, rather than HDL-C levels. In this regard, the study of functional CNS HDL-like lipoproteins is still in its infancy and has great potential for improving our understanding on the role of the CNS lipoprotein cargo in AD prevention, and in providing therapeutic perspectives to increase HDL-like particle functionality. However, before projecting this type of pharmacological approach, the causality of dysfunctional HDL in AD development should be definitively ascertained. The available epidemiological studies, being mostly cross-sectional, have not provided sufficient proofs on this. Besides, other methodological issues should be addressed, such as the standardization of the measurement of apoE, apoJ, and PON1 activity. This problem mostly concerns the measurement of PON1 activity, due to the great heterogeneity in the selection of substrates, and in the conditions of the assays used, affecting the studies on this HDL-associated protein.

(2) Given the complexity of the blood-HDL proteome and lipidome, and the limited information available, future studies focusing on these two areas will be critical for not only a better understanding of the CNS HDL-like lipoprotein functions, but also for novel therapeutic strategies. Of importance is understanding the mechanism of HDL-like lipoproteins and their components in optimizing cerebrovascular health. Besides, it is pivotal to clarify how the use of imaging modalities and imaging biomarkers can facilitate detection of cerebrovascular health, $\mathrm{AD}$ diagnosis, and future therapeutic development. In this regard, advances in mass spectrometry sensitivity, the -omics fields, and data management of generated large datasets would ensure the feasibility of disentangling the HDL complexity in the coming years.

Author Contributions: Conceptualization, C.C., J.M. and F.Z.; methodology, C.C., J.M., F.Z., M.P.A. and B.P.; writing-original draft preparation, C.C., J.M., F.Z., M.P.A. and B.P.; writing-review and editing, C.C., J.M., F.Z., M.P.A. and B.P.; supervision, C.C. and G.Z.; funding acquisition, J.M. All authors have read and agreed to the published version of the manuscript.

Funding: This research was funded by the National Institutes of Health, grant P50 AG05136 (JM).

Conflicts of Interest: The authors declare no conflict of interest.

\section{References}

1. Prince, M.; Ali, G.C.; Guerchet, M.; Prina, A.M.; Albanese, E.; Wu, Y.T. Recent global trends in the prevalence and incidence of dementia, and survival with dementia. Alzheimer's Res. Ther. 2016, 8, 23. [CrossRef] [PubMed]

2. Swerdlow, R.H. Pathogenesis of Alzheimer's disease. Clin. Interv. Aging 2007, 2, 347-359. [PubMed]

3. Attems, J.; Jellinger, K.A. The overlap between vascular disease and Alzheimer's disease-Lessons from pathology. BMC Med. 2014, 12, 206. [CrossRef] [PubMed]

4. De la Torre, J.C. Alzheimer Disease as a Vascular Disorder. Stroke 2002, 3, 1152-1162. [CrossRef] [PubMed]

5. Button, E.B.; Robert, J.; Caffrey, T.M.; Fan, J.; Zhao, W.; Wellington, C.L. HDL from an Alzheimer's disease perspective. Curr. Opin. Lipidol. 2019, 30, 224-234. [CrossRef] [PubMed]

6. Merched, A.; Xia, Y.; Visvikis, S.; Serot, J.M.; Siest, G. Decreased high-density lipoprotein cholesterol and serum apolipoprotein AI concentrations are highly correlated with the severity of Alzheimer's disease. Neurobiol. Aging 2000, 21, 27-30. [CrossRef] 
7. Jomard, A.; Osto, E. High Density Lipoproteins: Metabolism, Function, and Therapeutic Potential. Front. Cardiovasc. Med. 2020, 7, 1-12. [CrossRef]

8. Atzmon, G.; Gabriely, I.; Greiner, W.; Davidson, D.; Schechter, C.; Barzilai, N. Plasma HDL levels highly correlate with cognitive function in exceptional longevity. J. Gerontol. Ser. A Biol. Sci. Med. Sci. 2002, 57, 712-715. [CrossRef]

9. Van Exel, E.; De Craen, A.J.M.; Gussekloo, J.; Houx, P.; Bootsma-Van Der Wiel, A.; Macfarlane, P.W.; Blauw, G.J.; Westendorp, R.G.J. Association between high-density lipoprotein and cognitive impairment in the oldest old. Ann. Neurol. 2002, 51, 716-721. [CrossRef]

10. Singh-Manoux, A.; Gimeno, D.; Kivimaki, M.; Brunner, E.; Marmot, M.G. Low HDL cholesterol is a risk factor for deficit and decline in memory in midlife the whitehall II study. Arterioscler. Thromb. Vasc. Biol. 2008, 28, 1556-1562. [CrossRef]

11. Reitz, C.; Tang, M.X.; Schupf, N.; Manly, J.J.; Mayeux, R.; Luchsinger, J.A. Association of higher levels of high-density lipoprotein cholesterol in elderly individuals and lower risk of late-onset Alzheimer disease. Arch. Neurol. 2010, 67, 1491-1497. [CrossRef] [PubMed]

12. Barzilai, N.; Atzmon, G.; Derby, C.A.; Bauman, J.M.; Lipton, R.B. A genotype of exceptional longevity is associated with preservation of cognitive function. Neurology 2006, 67, 2170-2175. [CrossRef] [PubMed]

13. Cervellati, C.; Vigna, G.B.; Trentini, A.; Sanz, J.M.; Zimetti, F.; Dalla Nora, E.; Morieri, M.L.; Zuliani, G.; Passaro, A. Paraoxonase-1 activities in individuals with different HDL circulating levels: Implication in reverse cholesterol transport and early vascular damage. Atherosclerosis 2019, 285, 64-70. [CrossRef] [PubMed]

14. Vigna, G.B.; Satta, E.; Bernini, F.; Boarini, S.; Bosi, C.; Giusto, L.; Pinotti, E.; Tarugi, P.; Vanini, A.; Volpato, S.; et al. Flow-mediated dilation, carotid wall thickness and HDL function in subjects with hyperalphalipoproteinemia. Nutr. Metab. Cardiovasc. Dis. 2014, 24, 777-783. [CrossRef]

15. Lincoff, A.M.; Nicholls, S.J.; Riesmeyer, J.S.; Barter, P.J.; Brewer, H.B.; Fox, K.A.A.; Gibson, C.M.; Granger, C.; Menon, V.; Montalescot, G.; et al. Evacetrapib and Cardiovascular Outcomes in High-Risk Vascular Disease. N. Engl. J. Med. 2017, 376, 1933-1942. [CrossRef]

16. Boden, W.E. Niacin in Patients with Low HDL Cholesterol Levels Receiving Intensive Statin Therapy. N. Engl. J. Med. 2011, 365, 2255-2267.

17. Haase, C.L.; Tybjærg-Hansen, A.; Ali Qayyum, A.; Schou, J.; Nordestgaard, B.G.; Frikke-Schmidt, R. LCAT, HDL cholesterol and ischemic cardiovascular disease: A mendelian randomization study of HDL cholesterol in 54,500 individuals. J. Clin. Endocrinol. Metab. 2012, 97, 248-256. [CrossRef]

18. Rosenson, R.S.; Brewer, H.B.; Ansell, B.; Barter, P.J.; Chapman, M.J.; Heinecke, J.W.; Kontush, A.; Tall, A.R.; Webb, N.R. Dysfunctional HDL and atherosclerotic cardiovascular disease. Nat. Rev. Cardiol 2016, 13, 48-60. [CrossRef]

19. Rohatgi, A.; Khera, A.; Berry, J.D.; Givens, E.G.; Ayers, C.R.; Wedin, K.E.; Neeland, I.J.; Yuhanna, I.S.; Rader, D.R.; De Lemos, J.A.; et al. HDL cholesterol efflux capacity and incident cardiovascular events. N. Engl. J. Med. 2014, 371, 2383-2393. [CrossRef]

20. Camont, L.; Chapman, M.J.; Kontush, A. Biological activities of HDL subpopulations and their relevance to cardiovascular disease. Trends Mol. Med. 2011, 17, 594-603. [CrossRef]

21. Chieko Mineo, P.; Philip, W.; Shaul, M. Novel Biological Functions of HDL Cholesterol. Circ Res. 2012, 111, 1079-1090. [CrossRef] [PubMed]

22. Moren, X.; Lhomme, M.; Bulla, A.; Sanchez, J.C.; Kontush, A.; James, R.W. Proteomic and lipidomic analyses of paraoxonase defined high density lipoprotein particles: Association of paraoxonase with the anti-coagulant, protein S. Proteom. Clin. Appl. 2016, 10, 230-238. [CrossRef] [PubMed]

23. Fisher, E.A.; Feig, J.E.; Hewing, B.; Hazen, S.L.; Smith, J.D. High-density lipoprotein function, dysfunction, and reverse cholesterol transport. Arterioscler. Thromb. Vasc. Biol. 2012, 32, 2813-2820. [CrossRef] [PubMed]

24. Martínez-López, D.; Camafeita, E.; Cedó, L.; Roldan-Montero, R.; Jorge, I.; García-Marqués, F.; Gómez-Serrano, M.; Bonzon-Kulichenko, E.; Blanco-Vaca, F.; Blanco-Colio, L.M.; et al. APOA1 oxidation is associated to dysfunctional high-density lipoproteins in human abdominal aortic aneurysm. EBioMedicine 2019, 43, 43-53. [CrossRef]

25. Camps, J.; Marsillach, J.; Joven, J. The paraoxonases: Role in human diseases and methodological difficulties in measurement. Crit. Rev. Clin. Lab. Sci. 2009, 46, 83-106. [CrossRef] 
26. Patra, S.K.; Singh, K.; Singh, R. Paraoxonase 1: A better atherosclerotic risk predictor than HDL in type 2 diabetes mellitus. Diabetes Metab. Syndr. Clin. Res. Rev. 2013, 7, 108-111. [CrossRef]

27. Cervellati, C.; Romani, A.; Bergamini, C.M.; Bosi, C.; Sanz, J.M.; Passaro, A.; Zuliani, G. PON-1 and ferroxidase activities in older patients with mild cognitive impairment, late onset Alzheimer's disease or vascular dementia. Clin. Chem. Lab. Med. 2015, 53, 1049-1056. [CrossRef]

28. Castellazzi, M.; Trentini, A.; Romani, A.; Valacchi, G.; Bellini, T.; Bonaccorsi, G.; Fainardi, E.; Cavicchio, C.; Passaro, A.; Zuliani, G.; et al. Decreased arylesterase activity of paraoxonase-1 (PON-1) might be a common denominator of neuroinflammatory and neurodegenerative diseases. Int. J. Biochem. Cell Biol. 2016, 81, 356-363. [CrossRef]

29. Harel, M.; Aharoni, A.; Gaidukov, L.; Brumshtein, B.; Khersonsky, O.; Meged, R.; Dvir, H.; Ravelli, R.B.G.; McCarthy, A.; Toker, L.; et al. Structure and evolution of the serum paraoxonase family of detoxifying and anti-atherosclerotic enzymes. Nat. Struct. Mol. Biol. 2004, 11, 412-419. [CrossRef]

30. Gaidukov, L.; Tawfik, D.S. High affinity, stability, and lactonase activity of serum paraoxonase PON1 anchored on HDL with ApoA-I. Biochemistry 2005, 44, 11843-11854. [CrossRef]

31. Sorenson, R.C.; Bisgaier, C.L.; Aviram, M.; Hsu, C.; Billecke, S.; La Du, B.N. Human serum paraoxonase/arylesterase's retained hydrophobic N-terminal leader sequence associates with HDLs by binding phospholipids: Apolipoprotein A-I stabilizes activity. Arterioscler. Thromb. Vasc. Biol. 1999, 19, 2214-2225. [CrossRef] [PubMed]

32. Lewis, T.L.; Cao, D.; Lu, H.; Mans, R.A.; Su, Y.R.; Jungbauer, L.; Linton, M.F.; Fazio, S.; LaDu, M.J.; Li, L. Overexpression of human apolipoprotein A-I preserves cognitive function and attenuates neuroinflammation and cerebral amyloid angiopathy in a mouse model of alzheimer disease. J. Biol. Chem. 2010, 285, 36958-36968. [CrossRef] [PubMed]

33. Ciccone, L.; Shi, C.; Lorenzo, D.; Van Baelen, A.; Tonali, N. The Positive Side of the Alzheimer 's Disease Amyloid Cross Interactions: The case of Abeta 1-42 peptide with Tau, TTR, CysC and ApoA1. Molecules 2020, 25.

34. Zhou, A.L.; Swaminathan, S.K.; Curran, G.L.; Poduslo, J.F.; Lowe, V.J.; Li, L.; Kandimalla, K.K. Apolipoprotein A-I crosses the blood-brain barrier through clathrin-independent and cholesterol-mediated endocytosis. J. Pharmacol. Exp. Ther. 2019, 369, 481-488. [CrossRef]

35. Vitali, C.; Wellington, C.L.; Calabresi, L. HDL and cholesterol handling in the brain. Cardiovasc. Res. 2014, 103, 405-413. [CrossRef]

36. Van der Vorst, E.P.C. High-Density Lipoproteins and Apolipoprotein A1; Springer International Publishing: New York, NY, USA, 2020; Volume 94, ISBN 9783030417697.

37. Norum, K.R.; Remaley, A.; Miettinen, H.E.; Strøm, E.H.; Balbo, B.E.P.; Sampaio, C.A.T.L.; Wiig, I.; Kuivenhoven, J.A.; Calabresi, L.; Tesmer, J.J.; et al. Lecithin:cholesterol acyltransferase: Symposium on 50 years of biomedical research from its discovery to latest findings. J. Lipid Res. 2020, 61, 1142-1149. [CrossRef]

38. Lefterov, I.; Fitz, N.F.; Cronican, A.A.; Fogg, A.; Lefterov, P.; Kodali, R.; Wetzel, R.; Koldamova, R. Apolipoprotein A-I deficiency increases cerebral amyloid angiopathy and cognitive deficits in APP/PS1 $\triangle \mathrm{E} 9$ mice. J. Biol. Chem. 2010, 285, 36945-36957. [CrossRef]

39. Button, E.B.; Boyce, G.K.; Wilkinson, A.; Stukas, S.; Hayat, A.; Fan, J.; Wadsworth, B.J.; Robert, J.; Martens, K.M.; Wellington, C.L. ApoA-I deficiency increases cortical amyloid deposition, cerebral amyloid angiopathy, cortical and hippocampal astrogliosis, and amyloid-associated astrocyte reactivity in APP/PS1 mice. Alzheimer's Res. Ther. 2019, 11, 1-18. [CrossRef]

40. Koldamova, R.P.; Lefterov, I.M.; Lefterova, M.I.; Lazo, J.S. Apolipoprotein A-I directly interacts with amyloid precursor protein and inhibits A $\beta$ aggregation and toxicity. Biochemistry 2001, 40, 3553-3560. [CrossRef]

41. Sagare, A.P.; Bell, R.D.; Zlokovic, B.V. Neurovascular dysfunction and faulty amyloid $\beta$-peptide clearance in Alzheimer disease. Cold Spring Harb. Perspect. Med. 2012, 2, 1-17. [CrossRef] [PubMed]

42. Dal Magro, R.; Simonelli, S.; Cox, A.; Formicola, B.; Corti, R.; Cassina, V.; Nardo, L.; Mantegazza, F.; Salerno, D.; Grasso, G.; et al. The extent of human apolipoprotein A-1 lipidation strongly affects the $\beta$-amyloid efflux across the blood-brain barrier in vitro. Front. Neurosci. 2019, 13, 1-15. [CrossRef] [PubMed]

43. Contu, L.; Carare, R.O.; Hawkes, C.A. Knockout of apolipoprotein A-I decreases parenchymal and vascular $\beta$-amyloid pathology in the Tg2576 mouse model of Alzheimer's disease. Neuropathol. Appl. Neurobiol. 2019, 45, 698-714. [CrossRef] [PubMed] 
44. Slot, R.E.R.; Van Harten, A.C.; Kester, M.I.; Jongbloed, W.; Bouwman, F.H.; Teunissen, C.E.; Scheltens, P.; Veerhuis, R.; Van Der Flier, W.M. Apolipoprotein A1 in Cerebrospinal Fluid and Plasma and Progression to Alzheimer's Disease in Non-Demented Elderly. J. Alzheimer's Dis. 2017, 56, 687-697. [CrossRef] [PubMed]

45. Johansson, P.; Almqvist, E.G.; Bjerke, M.; Wallin, A.; Johansson, J.O.; Andreasson, U.; Blennow, K.; Zetterberg, H.; Svensson, J. Reduced Cerebrospinal Fluid Concentration of Apolipoprotein A-I in Patients with Alzheimer's Disease. J. Alzheimer's Dis. 2017, 59, 1017-1026. [CrossRef] [PubMed]

46. R\&D Insight Profile. Rvx 208. Drugs R D 2011, 11, 207-213. [CrossRef] [PubMed]

47. Bell, R.D.; Sagare, A.; Friedman, A.E.; Bedi, G.; David, M.; Deane, R.; Zlokovic, B. V Transport pathways for clearance of human Alzheimer's amyloid $\beta$-peptide and apolipoproteins $E$ and $\mathrm{J}$ in the mouse central nervous system. J. Cereb. Blood. Flow Metab. 2007, 27, 909-918. [CrossRef]

48. Paternò, R.; Ruocco, A.; Postiglione, A.; Hubsch, A.; Andresen, I.; Lang, M.G. Reconstituted high-density lipoprotein exhibits neuroprotection in two rat models of stroke. Cerebrovasc. Dis. 2004, 17, 204-211. [CrossRef]

49. Paula-Lima, A.C.; Tricerri, M.A.; Brito-Moreira, J.; Bomfim, T.R.; Oliveira, F.F.; Magdesian, M.H.; Grinberg, L.T.; Panizzutti, R.; Ferreira, S.T. Human apolipoprotein A-I binds amyloid- $\beta$ and prevents A $\beta$-induced neurotoxicity. Int. J. Biochem. Cell Biol. 2009, 41, 1361-1370. [CrossRef]

50. Husemann, J.; Loike, J.D.; Kodama, T.; Silverstein, S.C. Scavenger receptor class B type I (SR-BI) mediates adhesion of neonatal murine microglia to fibrillar $\beta$-amyloid. J. Neuroimmunol. 2001, 114, 142-150. [CrossRef]

51. Cai, L.; De Beer, M.C.; De Beer, F.C.; Van Der Westhuyzen, D.R. Serum amyloid a is a ligand for scavenger receptor class B type I and inhibits high density lipoprotein binding and selective lipid uptake. J. Biol. Chem. 2005, 280, 2954-2961. [CrossRef]

52. Krieger, M. Charting the fate of the "Good Cholesterol": Identification and characterization of the high-density lipoprotein receptor SR-BI. Annu. Rev. Biochem. 1999, 68, 523-558. [CrossRef] [PubMed]

53. Orth, M.; Weng, W.; Funke, H.; Steinmetz, A.; Assmann, G.; Nauck, M.; Dierkes, J.; Ambrosch, A.; Weisgraber, K.H.; Mahley, R.W.; et al. Effects of a frequent apolipoprotein E isoform, ApoE4Freiburg (Leu28->Pro), on lipoproteins and the prevalence of coronary artery disease in whites. Arterioscl. Thromb. Vasc. Biol. 1999, 19, 1306-1315. [CrossRef] [PubMed]

54. Al Mamun, A.; Sahab Uddin, M.; Fahim Bin Bashar, M.; Zaman, S.; Begum, Y.; Bulbul, I.J.; Siddiqul Islam, M.; Shahid Sarwar, M.; Mathew, B.; Shah Amran, M.; et al. Molecular insight into the therapeutic promise of targeting ApoE4 for Alzheimer's disease. Oxid. Med. Cell. Longev. 2020, 2020, 5086250. [CrossRef] [PubMed]

55. Rebeck, G.W.; Kindy, M.; LaDu, M.J. Apolipoprotein E and Alzheimer's disease: The protective effects of ApoE2 and E3. J. Alzheimer's Dis. 2002, 4, 145-154. [CrossRef]

56. Chernick, D.; Ortiz-Valle, S.; Jeong, A.; Qu, W.; Li, L. Peripheral Versus Central Nervous System APOE in Alzheimer's Disease: Interplay across the Blood-Brain Barrier. Neurosci. Lett. 2019, 708, 1173-1178. [CrossRef]

57. Ben-Aicha, S.; Badimon, L.; Vilahur, G. Advances in HDL: Much more than lipid transporters. Int. J. Mol. Sci. 2020, 21, 732. [CrossRef]

58. Yamazaki, Y.; Zhao, N.; Caulfield, T.R.; Liu, C.C.; Bu, G. Apolipoprotein E and Alzheimer disease: Pathobiology and targeting strategies. Nat. Rev. Neurol. 2019, 15, 501-518. [CrossRef]

59. Kloske, C.M.; Wilcock, D.M. The Important Interface Between Apolipoprotein E and Neuroinflammation in Alzheimer's Disease. Front. Immunol. 2020, 11, 1-12. [CrossRef]

60. Verghese, P.B.; Castellano, J.M.; Garai, K.; Wang, Y.; Jiang, H.; Shah, A.; Bu, G.; Frieden, C.; Holtzman, D.M. ApoE influences amyloid- $\beta$ (A $\beta$ ) clearance despite minimal apoE/A $\beta$ association in physiological conditions. Proc. Natl. Acad. Sci. USA 2013, 110, E1807-E1816. [CrossRef]

61. Tachibana, M.; Holm, M.L.; Liu, C.C.; Shinohara, M.; Aikawa, T.; Oue, H.; Yamazaki, Y.; Martens, Y.A.; Murray, M.E.; Sullivan, P.M.; et al. APOE4-mediated amyloid- $\beta$ pathology depends on its neuronal receptor LRP1. J. Clin. Investig. 2019, 129, 1272-1277. [CrossRef]

62. Shi, Y.; Yamada, K.; Liddelow, S.A.; Smith, S.T.; Zhao, L.; Luo, W.; Tsai, R.M.; Spina, S.; Grinberg, L.T.; Holtzman, D.M. APOE4 markedly exacerbates tau-mediated neurodegeneration in a mouse model of tauopathy. Nature 2017, 549, 523-527. [CrossRef] [PubMed]

63. Farfel, J.M.; Yu, L.; De Jager, P.L.; Schneider, J.A.; Bennett, D.A. Association of APOE with Tau-Tangle Pathology with and without $\beta$-amyloid. Neurobiol. Aging 2016, 176, 19-25. [CrossRef] [PubMed]

64. Wadhwani, A.R.; Affaneh, A.; Van Gulden, S.; Kessler, J.A. Neuronal apolipoprotein E4 increases cell death and phosphorylated tau release in alzheimer disease. Ann. Neurol. 2019, 85, 726-739. [CrossRef] [PubMed] 
65. Amponsah, A.E.; Feng, B.; Guo, R.; Zhang, W.; He, J. Fragmentation of brain apolipoprotein E (ApoE) and its relevance in Alzheimer's disease. Rev. Neurosci. 2020, 31, 589-603. [CrossRef]

66. Muñoz, S.S.; Garner, B.; Ooi, L. Understanding the Role of ApoE Fragments in Alzheimer's Disease. Neurochem. Res. 2019, 44, 1297-1305. [CrossRef]

67. Mouchard, A.; Boutonnet, M.C.; Mazzocco, C.; Biendon, N.; Macrez, N. ApoE-fragment/A $\beta$ heteromers in the brain of patients with Alzheimer's disease. Sci. Rep. 2019, 9, 1-13. [CrossRef]

68. Mahley, R.W. Central Nervous System Lipoproteins: ApoE and regulation of cholesterol metabolism. Arterioscler. Thromb. Vasc. Biol. 2016, 36, 1305-1315. [CrossRef]

69. Herz, J.; Bock, H.H. Lipoprotein receptors in the nervous system. Annu. Rev. Biochem. 2002, 71, $405-434$. [CrossRef]

70. Heinsinger, N.M.; Gachechiladze, M.A.; Rebeck, G.W. Apolipoprotein e genotype affects size of ApoE complexes in cerebrospinal fluid. J. Neuropathol. Exp. Neurol. 2016, 75, 918-924. [CrossRef]

71. Minagawa, H.; Gong, J.-S.; Jung, C.-G.; Watanabe, A.; Lund-Katz, S.; Phillips, M.C.; Saito, H.; Michikawa, M. Mechanism Underlying Apolipoprotein E (ApoE) Isoform- dependent Lipid Efflux From Neural Cells in Culture. J. Neurosci. Res. 2009, 87, 2498-2508. [CrossRef]

72. Rawat, V.; Wang, S.; Sima, J.; Bar, R.; Liraz, O.; Gundimeda, U.; Parekh, T.; Chan, J.; Johansson, J.O.; Tang, C.; et al. ApoE4 Alters ABCA1 Membrane Trafficking in Astrocytes. J. Neurosci. 2019, 39, 9611-9622. [CrossRef] [PubMed]

73. Marchi, C.; Adorni, M.P.; Caffarra, P.; Ronda, N.; Spallazzi, M.; Barocco, F.; Galimberti, D.; Bernini, F.; Zimetti, F. ABCA1-And ABCG1-mediated cholesterol efflux capacity of cerebrospinal fluid is impaired in Alzheimer's disease. J. Lipid Res. 2019, 60, 1449-1456. [CrossRef] [PubMed]

74. Yassine, H.N.; Feng, Q.; Chiang, J.; Petrosspour, L.M.; Fonteh, A.N.; Chui, H.C.; Harrington, M.G. ABCA1-Mediated Cholesterol Efflux Capacity to Cerebrospinal Fluid Is Reduced in Patients With Mild Cognitive Impairment and Alzheimer's Disease. J. Am. Heart Assoc. 2016, 5, 1-10. [CrossRef] [PubMed]

75. Seidah, N.G.; Benjannet, S.; Wickham, L.; Marcinkiewicz, J.; Bélanger Jasmin, S.; Stifani, S.; Basak, A.; Prat, A.; Chrétien, $\mathrm{M}$. The secretory proprotein convertase neural apoptosis-regulated convertase 1 (NARC-1): Liver regeneration and neuronal differentiation. Proc. Natl. Acad. Sci. USA 2003, 100, 928-933. [CrossRef]

76. O'Connell, E.M.; Lohoff, F.W. Proprotein Convertase Subtilisin/Kexin Type 9 (PCSK9) in the Brain and Relevance for Neuropsychiatric Disorders. Front. Neurosci. 2020, 14, 1-12. [CrossRef]

77. Zimetti, F.; Caffarra, P.; Ronda, N.; Favari, E.; Adorni, M.P.; Zanotti, I.; Bernini, F.; Barocco, F.; Spallazzi, M.; Galimberti, D.; et al. Increased PCSK9 cerebrospinal fluid concentrations in Alzheimer's disease. J. Alzheimer's Dis. 2017, 55, 315-320. [CrossRef]

78. Picard, C.; Poirier, A.; Bélanger, S.; Labonté, A.; Auld, D.; Poirier, J. Proprotein convertase subtilisin/kexin type 9 (PCSK9) in Alzheimer's disease: A genetic and proteomic multi-cohort study. PLoS ONE 2019, 14, e0220254. [CrossRef]

79. Montagne, A.; Nation, D.A.; Sagare, A.P.; Barisano, G.; Sweeney, M.D.; Chakhoyan, A.; Pachicano, M.; Joe, E.; Nelson, R.; Orazio, L.M.D.; et al. APOE4 leads to blood-brain barrier dysfunction predicting cognitive decline. Nature 2020, 581, 71-76. [CrossRef]

80. Arunsak, B.; Pratchayasakul, W.; Amput, P.; Chattipakorn, K.; Tosukhowong, T.; Kerdphoo, S.; Jaiwongkum, T.; Thonusin, C.; Palee, S.; Chattipakorn, N.; et al. Proprotein convertase subtilisin/kexin type 9 (PCSK9) inhibitor exerts greater efficacy than atorvastatin on improvement of brain function and cognition in obese rats. Arch. Biochem. Biophys. 2020,689, 108470. [CrossRef]

81. Pocivavsek, A.; Rebeck, G.W. Inhibition of C-Jun N-Terminal Kinase Increases ApoE Expression In vitro and In vivo. Biochem. Biophys. Res. Commun. 2009, 387, 516-520. [CrossRef]

82. Wong, M.Y.; Lewis, M.; Doherty, J.J.; Shi, Y.; Cashikar, A.G.; Amelianchik, A.; Tymchuk, S.; Sullivan, P.M.; Qian, M.; Covey, D.F.; et al. 25-Hydroxycholesterol amplifies microglial IL-1 $\beta$ production in an apoE isoform-dependent manner. J. Neuroinflam. 2020, 17, 1-17. [CrossRef] [PubMed]

83. Lynch, J.R.; Tang, W.; Wang, H.; Vitek, M.P.; Bennett, E.R.; Sullivan, P.M.; Warner, D.S.; Laskowitz, D.T. APOE genotype and an ApoE-mimetic peptide modify the systemic and central nervous system inflammatory response. J. Biol. Chem. 2003, 278, 48529-48533. [CrossRef] [PubMed]

84. Ramassamy, C.; Averill, D.; Beffert, U.; Theroux, L.; Lussier-Cacan, S.; Cohn, J.S.; Christen, Y.; Schoofs, A.; Davignon, J.; Poirier, J. Oxidative insults are associated with apolipoprotein E genotype in Alzheimer's disease brain. Neurobiol. Dis. 2000, 7, 23-37. [CrossRef] [PubMed] 
85. Tao, Q.; Ang, T.F.A.; DeCarli, C.; Auerbach, S.H.; Devine, S.; Stein, T.D.; Zhang, X.; Massaro, J.; Au, R.; Qiu, W.Q. Association of Chronic Low-grade Inflammation With Risk of Alzheimer Disease in ApoE4 Carriers. JAMA Netw. Open 2018, 1, e183597. [CrossRef]

86. Di Domenico, F.; Pupo, G.; Giraldo, E.; Badìa, M.C.; Monllor, P.; Lloret, A.; Eugenia Schininà, M.; Giorgi, A.; Cini, C.; Tramutola, A.; et al. Oxidative signature of cerebrospinal fluid from mild cognitive impairment and Alzheimer disease patients. Free Radic. Biol. Med. 2016, 91, 1-9. [CrossRef]

87. Taborda, N.A.; Blanquiceth, Y.; Urcuqui-Inchima, S.; Latz, E.; Hernandez, J.C. High-Density Lipoproteins Decrease Proinflammatory Activity and Modulate the Innate Immune Response. J. Interf. Cytokine Res. 2019, 39, 760-770. [CrossRef]

88. Butterfield, D.A.; Johnson, L.A. APOE in Alzheimer's disease and neurodegeneration. Neurobiol. Dis. 2020, 139, 1-3. [CrossRef]

89. Persson, T.; Lattanzio, F.; Calvo-Garrido, J.; Rimondini, R.; Rubio-Rodrigo, M.; Sundström, E.; Maioli, S.; Sandebring-Matton, A.; Cedazo-Mínguez, Á. Apolipoprotein E4 Elicits Lysosomal Cathepsin D Release, Decreased Thioredoxin-1 Levels, and Apoptosis. J. Alzheimer's Dis. 2017, 56, 601-617. [CrossRef]

90. Blaschuk, O.; Burdzy, K.; Fritz, I.B. Purification and characterization of a cell-aggregating factor (clusterin), the major glycoprotein in ram rete testis fluid. J. Biol. Chem. 1983, 258, 7714-7720.

91. Murphy, B.F.; Kirszbaum, L.; Walker, I.D.; d'Apice, J.F. Sp-40,40, a newly identified normal human serum protein found in the SC5b-9 complex of complement and in the immune deposits in glomerulonephritis. J. Clin. Investig. 1988, 81, 1858-1864. [CrossRef]

92. De Silva, H.V.; Stuart, W.D.; Duvic, C.R.; Wetterau, J.R.; Ray, M.J.; Ferguson, D.G.; Albers, H.W.; Smith, W.R.; Harmony, J.A.K. A 70-kDa apolipoprotein designated ApoJ is a marker for subclasses of human plasma high density lipoproteins. J. Biol. Chem. 1990, 265, 13240-13247. [PubMed]

93. Fritz, I.B.; Murphy, B. Clusterin Insights into a multifunctional protein. Trends Endocrinol. Metab. 1993, 8, 41-45. [CrossRef]

94. Humphreys, D.T.; Carver, J.A.; Easterbrook-Smith, S.B.; Wilson, M.R. Clusterin has chaperone-like activity similar to that of small heat shock proteins. J. Biol. Chem. 1999, 274, 6875-6881. [CrossRef] [PubMed]

95. Wang, H.; Eckel, R.H. What are lipoproteins doing in the brain? Trends Endocrinol. Metab. 2014, $25,8-14$. [CrossRef]

96. Kim, N.; Yoo, J.C.; Han, J.Y.; Hwang, E.M.; Kim, Y.S.; Jeong, E.Y.; Sun, C.H.; Yi, G.S.; Roh, G.S.; Kim, H.J.; et al. Human nuclear clusterin mediates apoptosis by interacting with Bcl-XL through C-terminal coiled coil domain. J. Cell. Physiol. 2012, 227, 1157-1167. [CrossRef]

97. Fagan, A.M.; Holtzman, D.M.; Munson, G.; Mathur, T.; Schneider, D.; Chang, L.K.; Getz, G.S.; Reardon, C.A.; Lukens, J.; Shah, J.A.; et al. Unique lipoproteins secreted by primary astrocytes from wild type, apoE (-/-), and human apoE transgenic mice. J. Biol. Chem. 1999, 274, 30001-30007. [CrossRef]

98. Harold, D.; Abraham, R.; Hollingworth, P.; Sims, R.; Gerrish, A.; Hamshere, M.L.; Pahwa, J.S.; Moskvina, V.; Dowzell, K.; Williams, A.; et al. Genome-wide association study identifies variants at CLU and PICALM associated with Alzheimer's disease. Nat. Genet. 2009, 41, 1088-1093. [CrossRef]

99. Lambert, J.C.; Heath, S.; Even, G.; Campion, D.; Sleegers, K.; Hiltunen, M.; Combarros, O.; Zelenika, D.; Bullido, M.J.; Tavernier, B.; et al. Genome-wide association study identifies variants at CLU and CR1 associated with Alzheimer's disease. Nat. Genet. 2009, 41, 1094-1099. [CrossRef]

100. Tan, L.; Wang, H.F.; Tan, M.S.; Tan, C.C.; Zhu, X.C.; Miao, D.; Yu, W.J.; Jiang, T.; Tan, L.; Yu, J.T. Effect of CLU genetic variants on cerebrospinal fluid and neuroimaging markers in healthy, mild cognitive impairment and Alzheimer's disease cohorts. Sci. Rep. 2016, 6, 1-12. [CrossRef]

101. Nordestgaard, L.T.; Tybjaerg-Hansen, A.; Rasmussen, K.L.; Nordestgaard, B.G.; Frikke-Schmidt, R. Genetic variation in clusterin and risk of dementia and ischemic vascular disease in the general population-cohort studies and meta-analyses of 362,338 individuals. Atherosclerosis 2018, 275, e29-e30. [CrossRef]

102. Yang, C.; Wang, H.; Li, C.; Niu, H.; Luo, S.; Guo, X. Association between clusterin concentration and dementia: A systematic review and meta-analysis. Metab. Brain Dis. 2019, 34, 129-140. [CrossRef] [PubMed]

103. Shepherd, C.E.; Affleck, A.J.; Bahar, A.Y.; Carew-Jones, F.; Halliday, G.M. Intracellular and secreted forms of clusterin are elevated early in Alzheimer's disease and associate with both $\mathrm{A} \beta$ and tau pathology. Neurobiol. Aging 2020, 89, 129-131. [CrossRef] [PubMed] 
104. May, P.C.; Lampert-Etchells, M.; Johnson, S.A.; Poirier, J.; Masters, J.N.; Finch, C.E. Dynamics of gene expression for a hippocampal glycoprotein elevated in Alzheimer's disease and in response to experimental lesions in rat. Neuron 1990, 5, 831-839. [CrossRef]

105. Nilselid, A.M.; Davidsson, P.; Nägga, K.; Andreasen, N.; Fredman, P.; Blennow, K. Clusterin in cerebrospinal fluid: Analysis of carbohydrates and quantification of native and glycosylated forms. Neurochem. Int. 2006, 48, 718-728. [CrossRef] [PubMed]

106. Wang, J.; Zhang, X.; Zhu, B.; Fu, P. Association of clusterin levels in cerebrospinal fluid with synaptic degeneration across the Alzheimer's disease continuum. Neuropsychiatr. Dis. Treat. 2020, 16, 183-190. [CrossRef] [PubMed]

107. Thambisetty, M.; Simmons, A.; Velayudhan, L.; Hye, A.; Campbell, J.; Zhang, Y.; Wahlund, L.O.; Westman, E.; Kinsey, A.; Guntert, A. Association of Plasma Clusterin Concentration With Severity, Pathology, and Progression in Alzheimer Disease. Arch. Gen. Psychiatry 2010, 67, 739-748. [CrossRef] [PubMed]

108. Yerbury, J.J.; Wilson, M.R. Extracellular chaperones modulate the effects of Alzheimer's patient cerebrospinal fluid on A $\beta 1-42$ toxicity and uptake. Cell Stress Chaperones 2010, 15, 115-121. [CrossRef]

109. Nielsen, H.M.; Mulder, S.D.; Beliën, J.A.M.; Musters, R.J.P.; Eikelenboom, P.; Veerhuis, R. Astrocytic A $\beta 1-42$ uptake is determined by $\mathrm{A} \beta$-aggregation state and the presence of amyloid-associated proteins. Glia 2010, 58, 1235-1246. [CrossRef]

110. Cascella, R.; Conti, S.; Mannini, B.; Li, X.; Buxbaum, J.N.; Tiribilli, B.; Chiti, F.; Cecchi, C. Transthyretin suppresses the toxicity of oligomers formed by misfolded proteins in vitro. Biochim. Biophys. Acta Mol. Basis Dis. 2013, 1832, 2302-2314. [CrossRef]

111. DeMattos, R.B.; Cirrito, J.R.; Parsadanian, M.; May, P.C.; O’Dell, M.A.; Taylor, J.W.; Harmony, J.A.; Aronow, B.J.; Bales, K.R.; Paul, S.M.; et al. ApoE and Clusterin Cooperatively Suppress A $\beta$ Levels and Deposition. Neuron 2004, 41, 193-202. [CrossRef]

112. Qi, X.M.; Wang, C.; Chu, X.K.; Li, G.; Ma, J.F. Intraventricular infusion of clusterin ameliorated cognition and pathology in Tg6799 model of Alzheimer's disease. BMC Neurosci. 2018, 19, 2. [CrossRef] [PubMed]

113. Narayan, P.; Orte, A.; Clarke, R.W.; Bolognesi, B.; Ganzinger, K.A.; Meehan, S.; Wilson, M.R.; Christopher, M. The extracellular chaperone clusterin sequesters oligomeric forms of the A $\beta 1-40$ peptide. Nat. Struct. Mol. Biol. 2016, 19, 79-83. [CrossRef] [PubMed]

114. Narayan, P.; Holmström, K.M.; Kim, D.H.; Whitcomb, D.J.; Wilson, M.R.; St. George-Hyslop, P.; Wood, N.W.; Dobson, C.M.; Cho, K.; Abramov, A.Y.; et al. Rare individual amyloid- $\beta$ oligomers act on astrocytes to initiate neuronal damage. Biochemistry 2014, 53, 2442-2453. [CrossRef] [PubMed]

115. Picard, C.; Julien, C.; Frappier, J.; Miron, J.; Théroux, L.; Dea, D.; Breitner, J.C.S.; Poirier, J. Alterations in cholesterol metabolism-related genes in sporadic Alzheimer's disease. Neurobiol. Aging 2018, 66, 180. [CrossRef]

116. Merino-Zamorano, C.; De Retana, S.F.; Montañola, A.; Batlle, A.; Saint-Pol, J.; Mysiorek, C.; Gosselet, F.; Montaner, J.; Hernández-Guillamon, M. Modulation of Amyloid- $31-40$ Transport by ApoA1 and ApoJ Across an in vitro Model of the Blood-Brain Barrier. J. Alzheimer's Dis. 2016, 53, 677-691. [CrossRef]

117. DeMattos, R.B.; O'dell, M.A.; Parsadanian, M.; Taylor, J.W.; Harmony, J.A.K.; Bales, K.R.; Paul, S.M.; Aronow, B.J.; Holtzman, D.M. Clusterin promotes amyloid plaque formation and is critical for neuritic toxicity in a mouse model of Alzheimer's disease. Proc. Natl. Acad. Sci. USA 2002, 99, 10843-10848. [CrossRef]

118. De Retana, S.F.; Marazuela, P.; Solé, M.; Colell, G.; Bonaterra, A.; Sánchez-Quesada, J.L.; Montaner, J.; Maspoch, D.; Cano-Sarabia, M.; Hernández-Guillamon, M. Peripheral administration of human recombinant ApoJ/clusterin modulates brain beta-amyloid levels in APP23 mice. Alzheimer's Res. Ther. 2019, 11, 1-17. [CrossRef]

119. Uddin, M.S.; Kabir, M.T.; Begum, M.M.; Islam, M.S.; Behl, T.; Ashraf, M.G.M. Exploring the Role of CLU in the Pathogenesis of Alzheimer's Disease. Neurotox. Res. 2020, 60, 1-12. [CrossRef]

120. James, R.W.; Deakin, S.P. The importance of high-density lipoproteins for paraoxonase-1 secretion, stability, and activity. Free Radic. Biol. Med. 2004, 37, 1986-1994. [CrossRef]

121. Deakin, S.P.; Bioletto, S.; Bochaton-Piallat, M.L.; James, R.W. HDL-associated paraoxonase-1 can redistribute to cell membranes and influence sensitivity to oxidative stress. Free Radic. Biol. Med. 2011, 50, 102-109. [CrossRef]

122. Efrat, M.; Aviram, M. Macrophage paraoxonase 1 (PON1) binding sites. Biochem. Biophys. Res. Commun. 2008, 376, 105-110. [CrossRef] [PubMed] 
123. Marsillach, J.; Mackness, B.; Mackness, M.; Riu, F.; Beltrán, R.; Joven, J.; Camps, J. Immunohistochemical analysis of paraoxonases-1, 2, and 3 expression in normal mouse tissues. Free Radic. Biol. Med. 2008, 45, 146-157. [CrossRef] [PubMed]

124. Marsillach, J.; Camps, J.; Beltran-Debón, R.; Rull, A.; Aragones, G.; Maestre-Martínez, C.; Sabench, F.; Hernández, M.; Castillo, D.D.; Joven, J.; et al. Immunohistochemical analysis of paraoxonases-1 and 3 in human atheromatous plaques. Eur. J. Clin. Investig. 2011, 41, 308-314. [CrossRef] [PubMed]

125. Furlong, C.E.; Suzuki, S.M.; Stevens, R.C.; Marsillach, J.; Richter, R.J.; Jarvik, G.P.; Checkoway, H.; Samii, A.; Costa, L.G.; Griffith, A.; et al. Human PON1, a biomarker of risk of disease and exposure. Chem. Biol. Interact. 2010, 187, 355-361. [CrossRef]

126. Aldridge, W.N. Two Types of Esterase (A and B) hydrolysing p-nitrophenyl acetate propionate and butyrate, and a method for their determination. Biochem. J. 1952, 53, 110-117. [CrossRef]

127. Aldridge, W.N. Serum esterases. II. An tenzyme hydrolysing diethyl p-nitrophenyl phosphate (E600) and its identity with the A-esterase of mammalian sera. Biochem. J. 1953, 53, 117-124. [CrossRef]

128. Mackness, M.I.; Arrol, S.; Durringtorm, P.N. Paraoxonase prevents accumulation of lipoperoxides in low-density lipoprotein. FEBS Lett. 1991, 286, 152-154. [CrossRef]

129. Aviram, M.; Rosenblat, M.; Bisgaier, C.L.; Newton, R.S.; Primo-Parmo, S.L.; La Du, B.N. Paraoxonase inhibits high-density lipoprotein oxidation and preserves its functions: A possible peroxidative role for paraoxonase. J. Clin. Investig. 1998, 101, 1581-1590. [CrossRef]

130. Aviram, M.; Rosenblat, M. Paraoxonases 1, 2, and 3, oxidative stress, and macrophage foam cell formation during atherosclerosis development. Free Radic. Biol. Med. 2004, 37, 1304-1316. [CrossRef]

131. Furlong, C.E.; Marsillach, J.; Jarvik, G.P.; Costa, L.G. Paraoxonases-1, -2 and -3: What are their Functions? Clement. Chem. Biol. Interact. 2016, 259, 51-62. [CrossRef]

132. Davies, H.G.; Richter, R.J.; Keifer, M.; Broomfield, C.A.; Sowalla, J.; Furlong, C.E. The effect of the human serum paraoxonase polymorphism is reversed with diazoxon, soman and sarin. Nat. Genet. 1996, 14, $334-336$. [CrossRef] [PubMed]

133. Reiner, W.; Aldridge, W.N.; Hoskin, F.C. Enzymes Hydrolysing Organophosphorus Compounds; Wiley: New York, NY, USA, 1989. [CrossRef]

134. Sorenson, R.C.; Primo-Parmo, S.L.; Kuo, C.L.; Adkins, S.; Lockridge, O.; La Du, B.N. Reconsideration of the catalytic center and mechanism of mammalian paraoxonase/arylesterase. Proc. Natl. Acad. Sci. USA 1995, 92, 7187-7191. [CrossRef] [PubMed]

135. Khersonsky, O.; Tawfik, D.S. Structure-reactivity studies of serum paraoxonase PON1 suggest that its native activity is lactonase. Biochemistry 2005, 44, 6371-6382. [CrossRef] [PubMed]

136. Draganov, D.I.; Teiber, J.F.; Speelman, A.; Osawa, Y.; Sunahara, R.; La Du, B.N. Human paraoxonases (PON1, PON2, and PON3) are lactonases with overlapping and distinct substrate specificities. J. Lipid Res. 2005, 46, 1239-1247. [CrossRef] [PubMed]

137. Billecke, S.; Draganov, D.; Counsell, R.; Stetson, P.; Watson, C.; Hsu, C.; La Du, B.N. Human serum paraoxonase (PON1) isozymes $\mathrm{Q}$ and $\mathrm{R}$ hydrolyze lactones and cyclic carbonate esters. Drug Metab. Dispos. 2000, 28, 1335-1342. [PubMed]

138. Teiber, J.F.; Horke, S.; Haines, D.C.; Chowdhary, P.K.; Xiao, J.; Kramer, G.L.; Haley, R.W.; Draganov, D.I. Dominant role of paraoxonases in inactivation of the Pseudomonas aeruginosa quorum-sensing signal N-(3-oxododecanoyl)-L-homoserine lactone. Infect. Immun. 2008, 76, 2512-2519. [CrossRef] [PubMed]

139. Ozer, E.A.; Pezzulo, A.; Shih, D.M.; Chun, C.; Furlong, C.; Lusis, A.J.; Greenberg, E.P.; Zabner, J. Human and murine paraoxonase 1 are host modulators of Pseudomonas aeruginosa quorum-sensing. FEMS Microbiol. Lett. 2005, 253, 29-37. [CrossRef]

140. Primo-Parmo, S.L.; Sorenson, R.C.; Teiber, J.; La Du, B.N. The human serum paraoxonase/arylesterase gene (PON1) is one member of a multigene family. Genomics 1996, 33, 498-507. [CrossRef]

141. Adkins, S.; Gan, K.N.; Mody, M.; La Du, B.N. Molecular basis for the polymorphic forms of human serum paraoxonase/arylesterase: Glutamine or arginine at position 191, for the respective A or B allozymes. Am. J. Hum. Genet. 1993, 52, 598-608.

142. Hassett, C.; Richter, R.J.; Humbert, R.; Chapline, C.; John Crabb, O.W.; Curtis Omiecinski, O.J.; Furlong, C.E. Characterization of cDNA Clones Encoding Rabbit and Human Serum Paraoxonase: The Mature Protein Retains Its Signal Sequence+, ${ }^{*}$. Biochemistry 1991, 30, 10141-10149. [CrossRef] 
143. Eckerson, H.W.; Wyte, C.M.; La Du, B.N. The human serum paraoxonase/arylesterase polymorphism. Am. J. Hum. Genet. 1983, 35, 1126-1138. [PubMed]

144. Leviev, I.; James, R.W. Promoter polymorphisms of human paraoxonase PON1 gene and serum paraoxonase activities and concentrations. Arterioscler. Thromb. Vasc. Biol. 2000, 20, 516-521. [CrossRef] [PubMed]

145. Costa, L.G.; Vitalone, A.; Cole, T.B.; Furlong, C.E. Modulation of paraoxonase (PON1) activity. Biochem. Pharmacol. 2005, 69, 541-550. [CrossRef] [PubMed]

146. Camps, J.; Marsillach, J.; Joven, J. Pharmacological and Lifestyle Factors Modulating Serum Paraoxonase-1 Activity. Mini Rev. Med. Chem. 2012, 9, 911-920. [CrossRef]

147. Richter, R.J.; Jarvik, G.P.; Furlong, C.E. Paraoxonase 1 (PON1) Status and Substrate Hydrolysis. Toxicol. Appl. Pharmacol. 2009, 235, 1-9. [CrossRef]

148. Kotur-Stevuljevic, J.; Spasic, S.; Stefanovic, A.; Zeljkovic, A.; Bogavac-Stanojevic, N.; Kalimanovska-Ostric, D.; Spasojevic-Kalimanovska, V.; Jelic-Ivanovic, Z. Paraoxonase-1 (PON1) activity, but not PON1 Q192R phenotype, is a predictor of coronary artery disease in a middle-aged Serbian population. Clin. Chem. Lab. Med. 2006, 44, 1206-1213. [CrossRef]

149. Cervellati, C.; Valacchi, G.; Tisato, V.; Zuliani, G.; Marsillach, J. Evaluating the link between Paraoxonase-1 levels and Alzheimer's disease development. Minerva Med. 2019, 110, 238-250. [CrossRef]

150. Wills, A.M.; Landers, J.E.; Zhang, H.; Richter, R.J.; Caraganis, A.J.; Cudkowicz, M.E.; Furlong, C.E.; Brown, R.H. Paraoxonase 1 (PON1) organophosphate hydrolysis is not reduced in ALS. Neurology 2008, 70, 929-934. [CrossRef]

151. Romani, A.; Trentini, A.; van der Flier, W.M.; Bellini, T.; Zuliani, G.; Cervellati, C.; Teunissen, C.E. Arylesterase activity of paraoxonase- 1 in serum and cerebrospinal fluid of patients with alzheimer's disease and vascular dementia. Antioxidants 2020, 9, 456. [CrossRef]

152. Menini, T.; Gugliucci, A. Paraoxonase 1 in neurological disorders. Redox Rep. 2014, 19, 49-58. [CrossRef]

153. Nie, Y.; Luo, D.; Yang, M.; Wang, Y.; Xiong, L.; Gao, L.; Liu, Y.; Liu, H. A Meta-Analysis on the Relationship of the PON Genes and Alzheimer Disease. J. Geriatr. Psychiatry Neurol. 2017, 30, 303-310. [CrossRef] [PubMed]

154. Paragh, G.; Balla, P.; Katona, E.; Seres, I.; Égerházi, A.; Degrell, I. Serum paraoxonase activity changes in patients with Alzheimer's disease and vascular dementia. Eur. Arch. Psychiatry Clin. Neurosci. 2002, 252, 63-67. [CrossRef] [PubMed]

155. Zengi, O.; Karakas, A.; Ergun, U.; Senes, M.; Inan, L.; Yucel, D. Urinary 8-hydroxy-2'-deoxyguanosine level and plasma paraoxonase 1 activity with Alzheimer's disease. Clin. Chem. Lab. Med. 2012, 50, 529-534. [CrossRef] [PubMed]

156. Bednarz-Misa, I.; Berdowska, I.; Zboch, M.; Misiak, B.; Zieliński, B.; Płaczkowska, S.; Fleszar, M.; Wiśniewski, J.; Gamian, A.; Krzystek-Korpacka, M. Paraoxonase 1 decline and lipid peroxidation rise reflect a degree of brain atrophy and vascular impairment in dementia. Adv. Clin. Exp. Med. 2020, 29, 71-78. [CrossRef]

157. Bednarska-Makaruk, M.E.; Krzywkowski, T.; Graban, A.; Lipczyńska-ŁOjkowska, W.; Bochyńska, A.; Rodo, M.; Wehr, H.; Ryglewicz, D.K. Paraoxonase 1 (PON1) gene -108C >T and p.Q192R polymorphisms and arylesterase activity of the enzyme in patients with dementia. Folia Neuropathol. 2013, 51, 111-119. [CrossRef]

158. Marsillach, J.; Ferré, N.; Vila, M.C.; Lligoña, A.; Mackness, B.; Mackness, M.; Deulofeu, R.; Solá, R.; Parés, A.; Pedro-Botet, J.; et al. Serum paraoxonase-1 in chronic alcoholics: Relationship with liver disease. Clin. Biochem. 2007, 40, 645-650. [CrossRef]

159. Marsillach, J.; Martínez-Vea, A.; Marcas, L.; Mackness, B.; Mackness, M.; Ferré, N.; Joven, J.; Camps, J. Administration of exogenous erythropoietin $\beta$ affects lipid peroxidation and serum paraoxonase- 1 activity and concentration in predialysis patients with chronic renal disease and anaemia. Clin. Exp. Pharmacol. Physiol. 2007, 34, 347-349. [CrossRef]

160. Marsillach, J.; Aragonès, G.; Mackness, B.; Mackness, M.; Rull, A.; Beltrán-Debón, R.; Pedro-Botet, J.; Alonso-Villaverde, C.; Joven, J.; Camps, J. Decreased paraoxonase-1 activity is associated with alterations of high-density lipoprotein particles in chronic liver impairment. Lipids Health Dis. 2010, 9, 1-10. [CrossRef]

161. Parra, S.; Alonso-Villaverde, C.; Coll, B.; Ferré, N.; Marsillach, J.; Aragonès, G.; Mackness, M.; Mackness, B.; Masana, L.; Joven, J.; et al. Serum paraoxonase-1 activity and concentration are influenced by human immunodeficiency virus infection. Atherosclerosis 2007, 194, 175-181. [CrossRef]

162. Franco-Pons, N.; Marsillach, J.; Joven, J.; Camps, J.; Closa, D. Serum paraoxonase undergoes inhibition and proteolysis during experimental acute pancreatitis. J. Gastrointest. Surg. 2008, 12, 891-899. [CrossRef] 
163. Gaita, L.; Manzi, B.; Sacco, R.; Lintas, C.; Altieri, L.; Lombardi, F.; Pawlowski, T.L.; Redman, M.; Craig, D.W.; Huentelman, M.J.; et al. Decreased serum arylesterase activity in autism spectrum disorders. Psychiatry Res. 2010, 180, 105-113. [CrossRef] [PubMed]

164. Besler, C.; Heinrich, K.; Rohrer, L.; Doerries, C.; Riwanto, M.; Shih, D.M.; Chroni, A.; Yonekawa, K.; Stein, S.; Schaefer, N.; et al. Mechanisms underlying adverse effects of HDL on eNOS-activating pathways in patients with coronary artery disease. J. Clin. Investig. 2011, 121, 2693-2708. [CrossRef] [PubMed]

165. Aviram, M.; Rosenblat, M.; Billecke, S.; Erogul, J.; Sorenson, R.; Bisgaier, C.L.; Newton, R.S.; La Du, B. Human serum paraoxonase (PON 1) is inactivated by oxidized low density lipoprotein and preserved by antioxidants. Free Radic. Biol. Med. 1999, 26, 892-904. [CrossRef]

166. Huang, Y.; Wu, Z.; Riwanto, M.; Gao, S.; Levison, B.S.; Gu, X.; Fu, X.; Wagner, M.A.; Besler, C.; Gerstenecker, G.; et al. Myeloperoxidase, paraoxonase-1, and HDL form a functional ternary complex. J. Clin. Investig. 2013, 123, 3815-3828. [CrossRef] [PubMed]

167. Balazs, Z.; Panzenboeck, U.; Hammer, A.; Sovic, A.; Quehenberger, O.; Malle, E.; Sattler, W. Uptake and transport of high-density lipoprotein (HDL) and HDL-associated $\alpha$-tocopherol by an in vitro blood-brain barrier model. J. Neurochem. 2004, 89, 939-950. [CrossRef]

168. Fung, K.Y.; Wang, C.; Nyegaard, S.; Heit, B.; Fairn, G.D.; Lee, W.L. SR-BI mediated transcytosis of HDL in brain microvascular endothelial cells is independent of caveolin, clathrin, and PDZK1. Front. Physiol. 2017, 8, 1-16. [CrossRef]

169. Ben-David, M.; Elias, M.; Filippi, J.J.; Duñach, E.; Silman, I.; Sussman, J.L.; Tawfik, D.S. Catalytic versatility and backups in enzyme active sites: The case of serum paraoxonase 1. J. Mol. Biol. 2012, 418, 181-196. [CrossRef]

170. Gan, K.N.; Smolen, A.; Eckerson, H.W.; La Du, B.N. Purification of Human serum paraoxonase/arylesterase-Evidence for one esterase catalyzing both activities. DRUG Metab. Dispos. 1991, 19, 100-106.

171. Blatter, M.-C.; James, R.W.; Messmer, S.; Barja, F.; Pometta, D. Identification of a distinct human high-density lipoprotein subspecies defined by a lipoprotein-associated protein, K-45: Identity of K-45 with paraoxonase. Eur. J. Biochem. 1993, 211, 871-879. [CrossRef]

172. Oda, M.N.; Bielicki, J.K.; Berger, T.; Forte, T.M. Cysteine substitutions in apolipoprotein A-I primary structure modulate paraoxonase activity. Biochemistry 2001, 40, 1710-1718. [CrossRef]

173. Trentini, A.; Rosta, V.; Spadaro, S.; Bellini, T.; Rizzo, P.; Vieceli Dalla Sega, F.; Passaro, A.; Zuliani, G.; Gentili, V.; Campo, G.; et al. Development, optimization and validation of an absolute specific assay for active myeloperoxidase (MPO) and its application in a clinical context: Role of MPO specific activity in coronary artery disease. Clin. Chem. Lab. Med. 2020, 1, 1-10. [CrossRef] [PubMed]

174. Kunutsor, S.K.; Bakker, S.J.L.; James, R.W.; Dullaart, R.P.F. Serum paraoxonase-1 activity and risk of incident cardiovascular disease: The PREVEND study and meta-analysis of prospective population studies. Atherosclerosis 2016, 245, 143-154. [CrossRef] [PubMed]

175. Dantoine, T.F.; Debord, J.; Merle, L.; Lacroix-Ramiandrisoa, H.; Bourzeix, L.; Charmes, J.-P. Paraoxonase 1 activity: A new vascular marker of dementia? Ann. N. Y. Acad. Sci. 2002, 977, 96-101. [CrossRef] [PubMed]

176. Bednarska-Makaruk, M.; Graban, A.; Wiśniewska, A.; Łojkowska, W.; Bochyńska, A.; Gugała-Iwaniuk, M.; Sławińska, K.; Ługowska, A.; Ryglewicz, D.; Wehr, H. Association of adiponectin, leptin and resistin with inflammatory markers and obesity in dementia. Biogerontology 2017, 18, 561-580. [CrossRef]

Publisher's Note: MDPI stays neutral with regard to jurisdictional claims in published maps and institutional affiliations.

(C) 2020 by the authors. Licensee MDPI, Basel, Switzerland. This article is an open access article distributed under the terms and conditions of the Creative Commons Attribution (CC BY) license (http://creativecommons.org/licenses/by/4.0/). 